\title{
A flood vulnerability index for coastal cities and its use in assessing climate change impacts
}

\author{
S. F. Balica $\cdot$ N. G. Wright $\cdot$ F. van der Meulen
}

Received: 9 June 2011/Accepted: 20 May 2012/Published online: 16 June 2012

(C) The Author(s) 2012. This article is published with open access at Springerlink.com

\begin{abstract}
Worldwide, there is a need to enhance our understanding of vulnerability and to develop methodologies and tools to assess vulnerability. One of the most important goals of assessing coastal flood vulnerability, in particular, is to create a readily understandable link between the theoretical concepts of flood vulnerability and the day-to-day decision-making process and to encapsulate this link in an easily accessible tool. This article focuses on developing a Coastal City Flood Vulnerability Index (CCFVI) based on exposure, susceptibility and resilience to coastal flooding. It is applied to nine cities around the world, each with different kinds of exposure. With the aid of this index, it is demonstrated which cities are most vulnerable to coastal flooding with regard to the system's components, that is, hydro-geological, socio-economic and politico-administrative. The index gives a number from 0 to 1 , indicating comparatively low or high coastal flood vulnerability, which shows which cities are most in need of further, more detailed investigation for decision-makers. Once its use to compare the vulnerability of a range of cities under current conditions has been demonstrated, it is used to study the impact of climate change on the vulnerability of these cities over a longer timescale. The results show that CCFVI provides a means of obtaining a broad overview of flood vulnerability and the effect of possible adaptation options. This, in turn, will allow for the direction of resources to more in-depth investigation of the most promising strategies.
\end{abstract}

Keywords Coastal City Flood Vulnerability Index (CCFVI) - Urbanised deltas · Climate change

S. F. Balica $(\bowtie) \cdot$ N. G. Wright $\cdot$ F. van der Meulen

UNESCO-IHE, Institute for Water Education, PO Box 3015, 2601 DA Delft, The Netherlands

e-mail: s.balica@unesco-ihe.org

S. F. Balica · N. G. Wright

Delft University of Technology, Postbus 5, 2600 AA Delft, The Netherlands

N. G. Wright

School of Civil Engineering, University of Leeds, Leeds LS2 9JT, UK

F. van der Meulen

Deltares, Postbus 177, 2600 MH Delft, The Netherlands 


\section{Introduction}

Coasts are highly dynamic and geo-morphologically complex systems, which respond in various ways to extreme weather events. Coastal floods are regarded as among the most dangerous and harmful of natural disasters (Douben 2006). It is well known that the urban areas adjacent to the shorelines are associated with large and growing concentrations of human population, settlements and socio-economic activities. Considering the fact that $21 \%$ of the world's population lives within coastal zones (du Gommes et al. 1997; Brooks et al. 2006), the potential impacts of sea-level rise are significant for the wider coastal ecosystem (Kumar 2006). Hoozemans et al. 1993 carried out a global vulnerability assessment and estimated that, under current conditions, an average of 46 million people per year experience storm-surge flooding. Baarse (1995) suggests that some 189 million people presently live below the one-in-a-hundred-year storm-surge level. There is therefore a need for a readily calculated and easily understood method to calculate flood vulnerability in such areas. In this work, we build on earlier work on a flood vulnerability index in river basins (Balica et al. 2009) to establish a flood vulnerability index using a composite method. This index can then be used to identify the most vulnerable coastal cities, develop adaptation measures for them and assess the effects of future change scenarios.

In this article, the focus is on large cities in low-lying deltaic environments with soft sedimentary coasts (estuaries, lagoons, mangroves, dunes, beaches). These cities experience both the influence of river discharge and of the sea and they are, by consequence, very vulnerable to impacts of climate change.

The paper focuses on coastal flood vulnerability and the systems approach in Sect. 2. In Sect. 3, the development of Coastal City Flood Vulnerability Index methodology is presented, and in Sect. 4, this is applied to assess the FVI of different deltaic cities. This is followed by an examination of the effects of the climate change impacts on the CCFVI in Sect. 5. Discussion and conclusions in Sects. 6 and 7 respectively follow this.

\section{Defining coastal system and coastal flood vulnerability}

It is expected that, due to climate change, coastal communities around the world will be increasingly affected by floods. In fact, some are already considered vulnerable to ongoing climatic variability (IPCC 2007a, b; Mirza 2003). Climate change is expected to cause accelerated sea-level rise with elevated tidal inundation, increased flood frequency, accelerated erosion, rising water tables, increased saltwater intrusion, increasing storm surges and increasing frequency of cyclones (Fenster and Dolan 1996). Apart from this, population growth and increasing urbanisation cause marine and coastal degradation (UNEP, GEO-3 2002).

\subsection{What is a coastal system?}

Coasts are dynamic systems, undergoing adjustments of form and process (termed morphodynamics) at different time and space scales in response to geo-morphological and oceanographical factors (Cowell et al. 2003a, b). Human activity exerts additional pressures that may dominate over natural processes. Coastal landforms, affected by short-term perturbations such as storms, generally return to their pre-disturbance morphology, implying a simple, morphodynamic equilibrium (Woodroffe 2003; Crooks 2004). 
The natural variability of coasts can make it difficult to identify the impacts of climate change. For example, most beaches worldwide show evidence of recent erosion, but sealevel rise is not necessarily the primary driver. Erosion can result from other factors, such as altered wind patterns (Pirazzoli et al. 2004; Pritchard 1967; Regnauld et al. 2004), offshore bathymetric changes (Cooper and Navas 2004), or reduced fluvial sediment input (Nicholls et al. 2007), or hard structures built near the coast.

\subsubsection{Natural coastal systems}

The IPCC (2007a, b) distinguishes between the following natural coastal systems: deltas, estuaries and lagoons, beaches, rocky shorelines and cliffed coasts, mangroves, sea grasses and coral reefs. In this paper, we focus on large urban areas situated in deltas. A delta is an area where the river sediment is building out into the sea. Deltas are biologically rich and diverse systems with waterfowls, fish and vegetation, and they support a large economic system based on tourism, agriculture, hunting, fishing, harbour and industry development (EC-JRC 2005; Prakasa and Murty 2005). Consequently, deltas are often densely populated (Ericson et al. 2006). IPCC (2007a, b). Many people in deltas are already subject to flooding from both storm surges and seasonal river floods, and therefore, it is necessary to develop further methods to assess flood vulnerability of coastal cities.

\subsection{Coastal flood vulnerability}

Vulnerability is considered as the extent of harm, which can be expected under certain conditions of exposure, susceptibility and resilience (Balica et al. 2009; Hufschmidt 2011; Scheuer et al. 2010; Willroth et al. 2010; Fuchs et al. 2011). More specifically in the case of floods, a system is susceptible to floods due to exposure in conjunction with its capacity/ incapacity to be resilient, to cope, recover or adapt to the extent.

Large populations are found in coastal areas where the exposure to coastal floods is high (Small and Nicholls 2003). The number of people affected is likely to increase, due to net coastward migration across the globe (Bijlsma et al. 1995). On the one hand, some of the exposed populations are protected from flooding by various structural and non-structural measures that are part of the resilience strategy. On the other hand, some of them have none, or only weak, flood defences and the exposed populations are more often subject to flooding with the consequent disruption, economic loss and loss of life. Smith and Ward 1998 showed that rising sea levels will raise flood levels; it is also estimated that the number of people flooded in a typical year by storm surges would increase 6 times and 14 times given a 0.5 - and 1.0-m rise in global sea levels, respectively (Nicholls 2004).

\subsubsection{Coastal vulnerability indices}

Vulnerability indices have been developed as a rapid and consistent method for characterising the relative vulnerability of different areas. The simplest of these are assessments of the physical vulnerability of the area, while the more complex also examine aspects of economic and social vulnerability. A summary of various indices applied globally is given here.

In previous work on coastal vulnerability, approaches were derived from Gornitz (1991), Gornitz and Kanciruk (1989), Thieler and Hammer-Klose (2000) with an index widely applied in the United States and in a modified form in Canada and parts of South 
Africa. It has also been viewed as important to incorporate social data on people at risk, the most detailed social vulnerability analysis being the synthesis by Boruff et al. (2005), Abuodha and Woodroffe (2007) and Gornitz (1991). The social vulnerability index (SoVI) uses "initially 42 socio-economic variables, reduced to 11 statistically independent factors" (i.e. age, race, ethnicity, education, family structure, social dependence, occupation) (Cutter et al. 2003). This being applied on a coastal county basis in a principal component analysis (PCA) to produce the overall coastal social vulnerability score (CSoVI). The coastal social vulnerability score (CSoVI) is a combination of variables for North America and Australia applied specifically to the beaches. The variables are dune height, barrier type, beach type, relative sea-level change, shoreline erosion and accretion, mean tidal range and mean wave height. In 2010, McLaughlin and Cooper developed a multi-scale coastal vulnerability index to investigate the implications of spatial scale in depicting coastal hazard risk, coastal vulnerabilities for national, local authority and site level. The authors in this index referred to coastal erosion vulnerability, either than coastal flood vulnerability. This can be seen in the variables which were used: a coastal characteristics sub-index concerned with the resilience and susceptibility of the coast to erosion, a coastal forcing sub-index to characterise the forcing variables contributing to wave-induced erosion and a socio-economic sub-index to assess the infrastructure potentially at risk. The socio-economic sub-index (McLaughlin and Cooper 2010) comprises 6 variables: population, roads (vital lines of communication and transport), cultural heritage, railways, land use and conservation status. Sharples (2006) uses identification and mapping of coastal substrates and landforms (i.e. geomorphic types) in order to assess coastal vulnerability which has greater or lesser sensitivity to potential coastal impacts of climate change and sea-level rise, such as accelerated erosion and shoreline recession, increased slumping or rock fall hazards, changing dune mobility and other hazards.

\subsection{Components of coastal flood vulnerability: the systems approach}

The systems approach aims to identify the interactions of different actors or components within certain defined boundaries. Van Beek (2006) identifies three interdependent subsystems in the coastal vulnerability system:

- The natural river subsystem (NS), in which the physical, chemical and biological processes take place;

- The socio-economic subsystem (SES), which includes the societal (human) activities related to the use of the natural river system; socio-economic systems are made up of rules and institutions that mediate human use of resources as well as systems of knowledge and ethics that interpret natural systems from a human perspective (Berkes and Folke 1998; Adger 2006).

- The administrative and institutional subsystem that includes administration, legislation and regulation, where the decision, planning and management processes take place.

Each of the three subsystems is characterised by its own elements, and it is surrounded within its own environment. In this paper, the vulnerability system is the coastal city. It can be seen as a set of interconnecting systems; the system is composed of interacting elements where different processes are carried out using various types of resources. In this context, one must define the system through its components and interactions. It should be shown how each element of the system, as well as the individual interactions, is vulnerable. For a better understanding of this paper, the delineation between terminologies is presented. 
Hazards have many origins, but in this paper, we normally view them as caused by the interaction between society and natural systems (e.g. precipitations, floods and cyclones). Unexpected hazards become visible rapidly, such as flooding or hurricanes, and last for a small period ranging from hours to weeks. Continuous hazards are very slow events that are barely perceptible by society such as sea-level rise. This paper considers both types of hazards. From the perspective of this research, vulnerability is embedded as a combination of the susceptibility of a given population, system or place to harm from exposure to the hazard and directly affects the ability to prepare for, respond to and recover from hazards and disasters. Resilience speaks to the capacity of the population, system, or place to buffer or adapt to changing hazard exposures.

The natural river system is delimited by climate and (hydro-geological) physical conditions (catchment and coast), the socio-economic system is formed by the demographic, social and economic conditions of the surrounding economies, and the administrative and institutional system is formed and bounded by the constitutional, legal and political system. Coastal floods distress three components of the coastal vulnerability system, each of them belongs to one of the subsystems described here, and their interactions affect the possible short-term and long-term damages. The components can be assessed by different indicators to understand the vulnerability of the system to coastal floods. The system components are hydro-geological, socio-economical and politico-administrative.

\subsubsection{Hydro-geological component}

The hydro-geological component is a part of the natural river system, being hazard dependent. It comprises hydro-geo-morphological (i.e. sea-level rise, river discharge, soil subsidence) and climatic (i.e. number of cyclones, storm surge) characteristics of the system. This component uses only the exposure indicators, see Eq. 3, because the system, here the city, is characterised from hydro-geological point of view (exposure) and the physical part, infrastructure (resilience), is taken into consideration under the socio-economic and politico-administrative component. The hydro-geological component continues to relate to the interrelation between the environment and the vulnerability associated with this interaction (Villagran de Leon 2006). Developments such as land subsidence, storm surge and high river discharge have enhanced environmental degradation, aggravating effects of climate change and associated sea-level rise, increasing the potential occurrence of floods. In this case, the hydro-geological component does not consider urbanisation and industrialisation as hazard.

\subsubsection{Socio-economic component}

The socio-economic component is part of the socio-economic system; the flooding affects the day-to-day lives of the population that belongs to the system. The socio component relates to the presence of human beings and encompasses issues related to it, for example deficiencies in mobility of human beings associated with gender, age or disabilities. Coastal floods can cause destruction of houses, disruption in communications, in the agricultural process, or even fatalities. The economic component is related to income or issues which are inherent to economics that are predisposed to being affected. There are many economic activities, which can be negatively affected by coastal flooding. Among them are tourism, fisheries, navigation, industries, agriculture, availability of potable water, etc. This influences the economic prosperity of a community, region, urban area or a 
country. McLaughlin and Cooper (2010) agreed that the choice of socio-economic variables adds an inherent cultural bias to an index.

\subsubsection{Politico-administrative component}

The politico-administrative component encompasses the administrative and institutional system. To characterise the administrative and institutional system, the relevant institutions at the national, regional and local level have to be identified. The approach assumes that one or more institutions have the ability and authority to develop and implement plans that will oversee and manage the coordinated development and operation of the actions of the local authorities that affect the coasts. This component embraces the exposure, susceptibility and resilience indicators (see Eq. 6).

The components can be assessed by using different indicators. These components have been linked with the three factors of vulnerability. The index aims to describe flood damage at coastal city level. Consequently, through this identification, decision-makers can make informed choices on how to best allocate resources to ameliorate flood damage in the future.

The relationship between the components affected by coastal floods and the subsystems of the coastal vulnerability system is shown in the Fig. 1.

Understanding the natural processes as well as the economic and social services or functions that coasts fulfil is critical to the successful and sustainable management of these systems.

Considering the coastal system, the NS gives/receives impacts to/from the SES by, that is, the impact of sea-level rise is obvious: more severe storms; while storm surge will decrease a little because of the larger water depths, it will also increase because of the more severe storm activity; tidal prisms will increase, etc. As a result, salt intrusion will increase, structures will be more stressed, and wetlands will be inundated and disappear (Covich

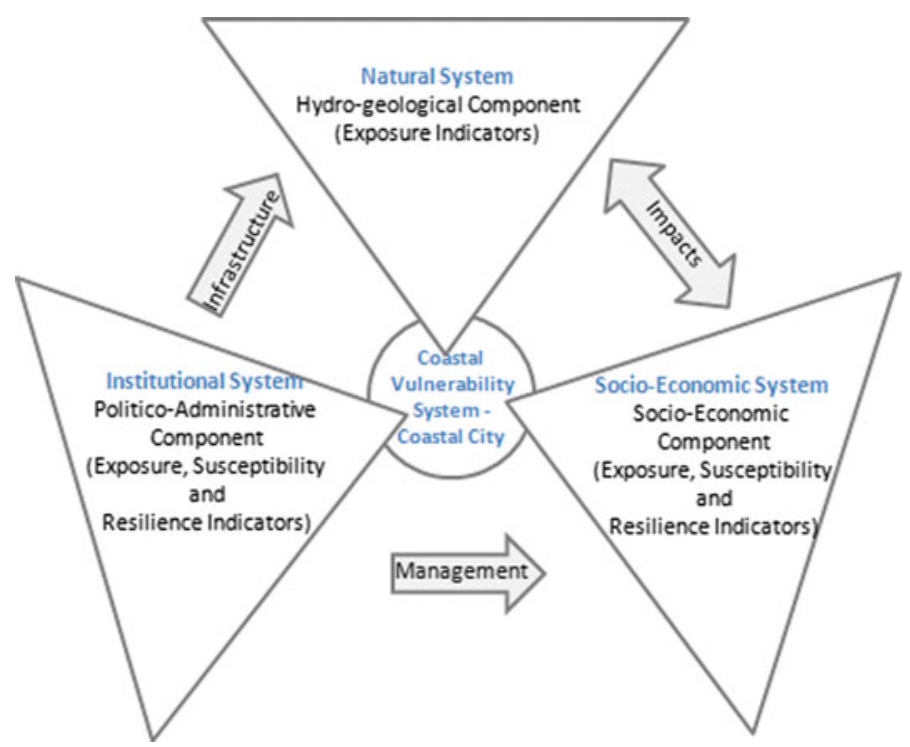

Fig. 1 Coastal vulnerability system: its sub-systems and interactions (modified from van Beek 2006) 
1993). All of these will affect the population along the coasts, which is permanently increasing (Hutchings and Collett 1977). Damage will also occur to agricultural areas because of the additional saltwater intrusion. The cultural heritage will be susceptible to flood (e.g. Venice and the Netherlands).

The coast is affected by human activities such as bank protection, shipping, and construction and operation of hydraulic infrastructures. The coasts provide tangible and direct economic benefits. Tourism and fisheries prosper on the wealth of natural resources coasts supply. The protected coastal waters also support important public infrastructure, serving as harbours and ports vital for shipping, transportation and industry. To maintain and enhance these and other services and benefits derived from coasts, they must be managed.

\section{Development of Coastal City Flood Vulnerability Index methodology}

\subsection{Flood vulnerability factors}

Societies are vulnerable to floods due to three main factors: exposure, susceptibility and resilience (Balica et al. 2009). The vulnerability of any system (at any scale) is reflective of (or a function of) the exposure and susceptibility of that system to hazardous conditions and the resilience of the system to adapt and/or recover from the effects of those conditions (Smit and Wandel 2006).

Exposure can be understood as the values that are present at the location where floods can occur. These values can be goods, infrastructure, cultural heritage, agricultural fields and people (UN 2003). Exposure is generally described as patterns and processes that estimate its intensity and duration (Balica et al. 2009). Fekete (2009) describes exposure as the measure of susceptible elements within a region threatened by a hazard, while in Penning-Rowsell et al. (2005), exposure is defined as the likelihood that humans and/or physical items (goods, infrastructure, cultural heritage and agricultural fields) will be impacted by flooding. In case of the CCFVI, here exposure is defined as "the predisposition of a system to be disrupted by a flooding event due to its location in the same area of influence".

The concept of susceptibility, or sensitivity, has developed through the years. For example, Penning-Rowsell and Chatterton defined susceptibility in 1977 as the relative damageability of property and materials during floods or other hazardous events. The IPCC (2001) argued susceptibility as the degree to which a system is affected, either adversely or beneficially, by climate-related stimuli. At this moment, the definition is still argued and is creating confusion between social and natural scientists.

Susceptibility relates to system characteristics, including the social context of flood damage, especially the awareness and preparedness of people regarding the risk they live with (before the flood), the institutions that are involved in mitigating and reducing the effects of the hazards and the existence of possible measures, like flood hazard maps to be used during the floods.

This paper defines susceptibility as the elements exposed within the system, which influence the probabilities of being harmed at times of hazardous floods.

The ability of individuals and social systems to handle the impact of floods is often correlated with general socio-economic indicators. The susceptibility indicators embrace general information on social relations, institutional development and population with special needs (children, elderly or disabled) (e.g. Blaikie et al. 1994; Watts and Bohle 1993). 


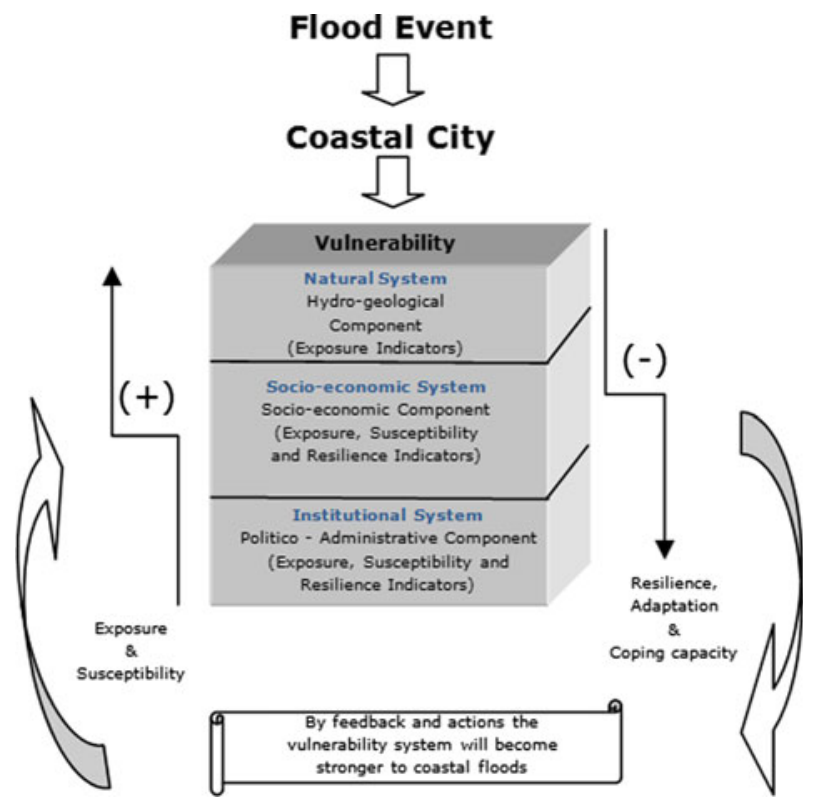

Fig. 2 Vulnerability system

Holling, originally, defined resilience in 1973 as "a measure of persistence of systems and their ability to absorb change and disturbance and still maintain the same relationships between populations and state variables". Resilience is the capacity of any kind of system, community, society or environment, potentially exposed to hazards to adapt to any change, by resisting or modifying itself, in order to maintain or to achieve an acceptable level of functioning and structure (Pelling 2003). Resilience is therefore analysed through a political, administrative, environmental and social organisational evaluation (Di Mauro 2006).

Based on Le Chatelier's principle (Hatta 1987), "Any change in status quo prompts an opposing reaction in the responding system". All systems are in hazard, but their vulnerability reflects the possible damages that can be expected in the case of an event. All the components of the system can be affected by floods. After each flooding event, the social system usually becomes stronger and gives feedback to reduce the vulnerability to future floods. A system at risk is more vulnerable when it is more exposed to a hazard and it is more susceptible to its forces and impacts (Fig. 2). However, the system will be less vulnerable when it is more resilient and less exposed.

\subsection{Coastal vulnerability indicators}

Vulnerability is considered here based on the use of indicators. An indicator, or set of indicators, can be defined as an inherent characteristic that quantitatively estimates the condition of a system; they usually focus on minor, feasible, palpable and telling piece of a system that can offer people a sense of the bigger representation. Therefore, it is very important to know the impacts on the people, cities, natural resources, via the use of these indicators. 
The first step in an indicator-based vulnerability assessment is to select appropriate indicators. The standard practice (Gornitz and Kanciruk 1989; Peduzzi et al. 2001; Briguglio 2003; Pratt et al. 2004; Adger and Vincent 2005; Guillaumont 2008) is to assemble a list of indicators using criteria such as suitability, following a conceptual framework or definitions, availability of data and sensitivity to formats, usefulness and ease of recollection.

McLaughlin and Cooper (2010) affirm that it is tempting to use all available data in the creation of an index. Earlier, Dal Cin and Simeoni (1989) claimed that using more numerous variables gave more correct results. This, however, is not necessarily true since variables/indicators can be highly correlated (Balica and Wright 2009).

Since the development of the FVI involves the understanding of different relational situations and characteristics of a coastal system exposed to flood risks, a deductive approach to identify the best possible indicators has been used, based on existing principles and the conceptual framework of vulnerability.

Understanding each concept and considering certain indicators may help to characterise the vulnerability of different systems, by which actions can be identified to decrease it. Every vulnerability factor (exposure, susceptibility and resilience) represents a set of constituent indicators, based on the characteristics of a coastal system, which can help to better understand the response of the coastal cities to floods.

Some of the indicators, in general, belong to two of the factors. Due to the definition in this study, the indicators are considered only for one of the factors. For example, Flood Protection (FP) indicator belongs to resilience factor, as being a positive measure; the method does not consider the Environmental Component where the FP indicator can be a negative measure. The Institutional Organisations (IO) indicator is one of the indicators used to index the politico-administrative component, and from the functional relationship with the vulnerability (Table 4), it can be seen that higher the number of IO, lower the vulnerability. The IO can be included under the susceptibility factor as well, but because of the difficulty in quantifying corruption, this indicator is not considered; the choice is to use it only as resilience indicator.

The relationship between coastal vulnerability components, indicators and factors is illustrated in Table 1. The availability of data, the importance of certain indicators and the condition that all FVIs computed must be dimensionless for the purposes of comparison led to the formulation of the equations for each vulnerability component.

\subsection{General flood vulnerability index equation related to coastal cities}

A general FVI equation (Eq. 1) for all scales is described by Balica et al. (2009). The equation links the values of all indicators to flood vulnerability components and factors (exposure, susceptibility and resilience), without weighting (Cendrero and Fischer 1997; Peduzzi et al. 2001; Briguglio 1992, 1993, 1995, 1997, 2003). This is done because of different number of rating judgments which "lie behind combined weights", or interpolating.

McLaughlin and Cooper (2010) use Gornitz (1990) approach, a scale of 1-5 is chosen, with 5 contributing most strongly to vulnerability and 1 contributing least. The $1-5$ scale that was used for every variable standardises the scoring system and enables variables measured in different units to be combined mathematically.

McLaughlin and Cooper (2010) use the approach of Gornitz and White (1992), which is based on the fact that the "sum of the variables was less sensitive than one based on the products of the variables". This research used the approach of FVI (Balica et al. 2009) 
Table 1 Relationship between components and factors

\begin{tabular}{|c|c|c|c|c|c|c|c|}
\hline \multirow{2}{*}{$\begin{array}{l}\text { Water } \\
\text { resources } \\
\text { system }\end{array}$} & \multirow{2}{*}{$\begin{array}{l}\text { Coastal flood } \\
\text { vulnerability } \\
\text { components }\end{array}$} & \multicolumn{6}{|c|}{ Vulnerability factors } \\
\hline & & Abb & Exposure & Abb & Susceptibility & Abb & Resilience \\
\hline \multicolumn{8}{|c|}{ Coastal Flood Vulnerability Indicators } \\
\hline \multirow[t]{5}{*}{ Natural } & Hydro-geological & $\begin{array}{l}\text { SLR } \\
\text { SS } \\
\# \text { Cyc }\end{array}$ & $\begin{array}{l}\text { Sea-level rise } \\
\text { Storm surge } \\
\# \text { of cyclones in } \\
\text { the last } \\
5 \text { years }\end{array}$ & \multirow{5}{*}{\multicolumn{2}{|c|}{$\begin{array}{l}\text { The hydro-geological } \\
\text { component does not } \\
\text { consider susceptibility } \\
\text { indicators for this method }\end{array}$}} & \multirow{5}{*}{\multicolumn{2}{|c|}{$\begin{array}{l}\text { The hydro-geological } \\
\text { component does not } \\
\text { consider resilience } \\
\text { indicators for this } \\
\text { method }\end{array}$}} \\
\hline & & $\mathrm{RD}$ & River discharge & & & & \\
\hline & & $\mathrm{SF}$ & Foreshore slope & & & & \\
\hline & & Soil & Soil subsidence & & & & \\
\hline & & $\mathrm{CL}$ & $\mathrm{km}$ of coastline & & & & \\
\hline \multirow[t]{2}{*}{ Social } & Social & PCL & $\begin{array}{l}\text { Population close } \\
\text { to } \mathrm{CL}\end{array}$ & \multirow[t]{2}{*}{$\%$} & $\begin{array}{l}\% \text { of disabled } \\
\text { persons }\end{array}$ & $\mathrm{S}$ & Shelters \\
\hline & & $\mathrm{CH}$ & $\begin{array}{l}\text { Cultural } \\
\text { heritage }\end{array}$ & & $\begin{array}{l}(<12 \text { and } \\
\quad>65 \text { years })\end{array}$ & $\mathrm{A} / \mathrm{P}$ & $\begin{array}{r}\text { Awareness and } \\
\text { preparedness }\end{array}$ \\
\hline \multirow[t]{2}{*}{ Economic } & Economic & GCP & $\begin{array}{l}\text { Growing coastal } \\
\text { population }\end{array}$ & \multirow{2}{*}{\multicolumn{2}{|c|}{$\begin{array}{l}\text { The economic component } \\
\text { does not consider } \\
\text { susceptibility indicators } \\
\text { for this method }\end{array}$}} & Drain & $\begin{array}{l}\mathrm{km} \text { of } \\
\text { Drainage }\end{array}$ \\
\hline & & & & & & RT & $\begin{array}{l}\text { Recovery } \\
\text { Time }\end{array}$ \\
\hline \multirow[t]{2}{*}{ Institutional } & $\begin{array}{l}\text { Politico- } \\
\text { administrative }\end{array}$ & UP & $\begin{array}{l}\text { Uncontrolled } \\
\text { planning }\end{array}$ & FHM & $\begin{array}{l}\text { Flood hazard } \\
\text { maps }\end{array}$ & IO & $\begin{array}{l}\text { Institutional } \\
\text { organisations }\end{array}$ \\
\hline & & & zones & & & FP & $\begin{array}{l}\text { Flood } \\
\text { protection }\end{array}$ \\
\hline
\end{tabular}

(Eq. 2), the approach is based on the fact that each system has its own vulnerability to floods, so a variable cannot be considered zero.

The procedure for calculating the CCFVI starts by converting each identified indicator into a normalised (on a scale from 0 to 1 ), dimensionless number using predefined minimum and maximum values from the spatial elements under consideration. Equation (1) shows the expression used for normalisation.

$$
\mathrm{NV}_{i}=\frac{\mathrm{RV}_{i}}{\operatorname{Max}_{i=1, n}\left(\mathrm{RVI}_{i}\right)}
$$

where $\mathrm{NV}_{i}$ represents the normalised value of the indicator $\mathrm{I}$, the $\mathrm{RV}_{i}$ represents the real value of the indicator I, and $\operatorname{Max}_{i=1, n}\left(\mathrm{RVI}_{i}\right)$ represents the maximum value from a set of $n$ computed real values of the indicator I (where $n$ is the number of spatial elements under consideration). Normalised indicators are subsequently used for CCFVI calculations.

The CCFVI of each coastal component (hydro-geological, social, economic and politico-administrative) is computed based on the general flood vulnerability index (FVI) formula (Eq. 2).

$$
\mathrm{FVI}=\frac{E * S}{R}
$$

The general formula for FVI is computed by categorising the indicators to the factors to which they belong (exposure $(E)$, susceptibility $(S)$ and resilience $(R)$ ) (Cendrero and Fischer 1997). The indicators of exposure and susceptibility are multiplied and then divided by the resilience indicators, because indicators representing exposure and 
susceptibility increase the flood vulnerability and are therefore placed in the numerator. The resilience indicators decrease flood vulnerability and are thus part of the denominator.

Equations of the coastal city scale for all the system components: the indicators play a gradually more significant policy role; also, they represent only synoptic sides of a system. The first step in an indicator-based vulnerability assessment is to select indicators (Adriaanse 1993; World Bank 1994, 1997; CRED 2010; Perry 2006; Quarantelli 2005; Sorenson and Sorensen 2006; Briguglio 2003; Peduzzi et al. 2001; Hughes and Brundrit 1992); for example, the detailed World Bank Africa Database 2005 consists of almost 1,200 indicators (World Bank 2005). The benchmark is to gather a list of proxies using the following criterion: suitability, definitions or the theoretical structure, availability of data.

As shown in Tables 2,3 and 4, a total number of 19 indicators are used in general to quantify the vulnerability of coastal areas. These 19 indicators were selected from World Bank data set, 2001, Gornitz (1990), McLaughlin and Cooper (2010) and Cutter et al. (2003), after using multi-collinearity analysis among 30 coastal indicators for 9 case studies (Balica and Wright 2010).

Coastal City Flood Vulnerability Index for Hydro-Geological Component was expressed as follows:

$$
\mathrm{FVI}_{\text {Hydro-Geological }}=f\{\mathrm{SLR}, \mathrm{SS}, \# \text { Cyc, FS, RD, Soil, CL }\}
$$

Table 2 Indicators information of the hydro-geological component

\begin{tabular}{|c|c|c|c|c|c|}
\hline Indicators & Abb. & Factor & Unit & Definition & $\begin{array}{l}\text { Functional } \\
\text { relationship with } \\
\text { vulnerability }\end{array}$ \\
\hline $\begin{array}{l}\text { Sea-level } \\
\text { rise }\end{array}$ & SLR & Exposure & $\begin{array}{l}\mathrm{mm} / \\
\text { year }\end{array}$ & $\begin{array}{l}\text { How much the level of the sea is increasing } \\
\text { in } 1 \text { year }\end{array}$ & $\begin{array}{l}\text { Higher SLR, } \\
\text { higher } \\
\text { vulnerability }\end{array}$ \\
\hline Storm surge & SS & Exposure & $\mathrm{cm}$ & $\begin{array}{l}\text { A storm surge is the rapid rise in the water } \\
\text { level surface produced by onshore } \\
\text { hurricane winds and falling barometric } \\
\text { pressure. }\end{array}$ & $\begin{array}{l}\text { Bigger increase } \\
\text { in WL, higher } \\
\text { vulnerability }\end{array}$ \\
\hline $\begin{array}{l}\text { \# of } \\
\text { cyclones }\end{array}$ & \#Сус & Exposure & \# & Number of cyclones in the last 10 years & $\begin{array}{l}\text { Higher \# of } \\
\text { Cyclones, } \\
\text { higher } \\
\text { vulnerability }\end{array}$ \\
\hline $\begin{array}{l}\text { River } \\
\text { discharge }\end{array}$ & $\mathrm{RD}$ & Exposure & $\mathrm{m}^{3} / \mathrm{s}$ & $\begin{array}{l}\text { Maximum discharge in record of the last } \\
10 \text { years, } \mathrm{m}^{3} / \mathrm{s}\end{array}$ & $\begin{array}{l}\text { Higher RD, } \\
\text { higher } \\
\text { vulnerability }\end{array}$ \\
\hline $\begin{array}{l}\text { Foreshore } \\
\text { slope }\end{array}$ & FS & Exposure & $\%$ & $\begin{array}{l}\text { Foreshore slope and depth of the sea near } \\
\text { the coast, can change a lot and often. } \\
\text { Average slope of the foreshore beach }\end{array}$ & $\begin{array}{l}\text { Lower slope, } \\
\text { higher } \\
\text { vulnerability }\end{array}$ \\
\hline $\begin{array}{l}\text { Soil } \\
\text { subsidence }\end{array}$ & Soil & Exposure & $\mathrm{m}^{2}$ & How much the area is decreasing? & $\begin{array}{l}\text { Higher areas, } \\
\text { higher } \\
\text { vulnerability }\end{array}$ \\
\hline Coastline & $\mathrm{CL}$ & Exposure & $\mathrm{km}$ & Kilometres of coastline along the city & $\begin{array}{l}\text { Longer CL, } \\
\text { higher } \\
\text { vulnerability }\end{array}$ \\
\hline
\end{tabular}


Table 3 Indicators information of the socio-economic component

\begin{tabular}{|c|c|c|c|c|c|}
\hline Indicators & Abb. & Factor & Unit & Definition & $\begin{array}{l}\text { Functional relationship } \\
\text { with vulnerability }\end{array}$ \\
\hline $\begin{array}{l}\text { Cultural } \\
\text { heritage }\end{array}$ & $\mathrm{CH}$ & Exposure & \# & $\begin{array}{l}\text { Number of historical } \\
\text { buildings, museums, } \\
\text { etc., in danger when } \\
\text { coastal flood occurs }\end{array}$ & $\begin{array}{l}\text { High \# of } \mathrm{CH} \text {, higher } \\
\text { the vulnerability }\end{array}$ \\
\hline $\begin{array}{l}\text { Population } \\
\text { close to } \\
\text { coastline }\end{array}$ & PCL & Exposure & People & $\begin{array}{l}\text { Number of people } \\
\text { exposed to coastal } \\
\text { hazard }\end{array}$ & $\begin{array}{l}\text { The higher number of } \\
\text { people, higher } \\
\text { vulnerability }\end{array}$ \\
\hline $\begin{array}{l}\text { Growing } \\
\text { coastal } \\
\text { population }\end{array}$ & GCP & Exposure & $\%$ & $\begin{array}{l}\% \text { of growth of } \\
\text { population in urban } \\
\text { areas in the last } \\
10 \text { years }\end{array}$ & $\begin{array}{l}\text { Fast GCP, higher } \\
\text { vulnerability, } \\
\text { hypothesis is made } \\
\text { that fast population } \\
\text { growth may create } \\
\text { pressing on land } \\
\text { subsidence }\end{array}$ \\
\hline Shelters & $\mathrm{S}$ & Resilience & \# & $\begin{array}{l}\text { Number of shelters per } \\
\mathrm{km}^{2} \text {, including } \\
\text { hospitals }\end{array}$ & $\begin{array}{l}\text { Bigger \# of } \mathrm{S} \text {, lower } \\
\text { vulnerability }\end{array}$ \\
\hline $\begin{array}{l}\% \text { of disabled } \\
\text { persons } \\
(<14 \text { and } \\
>65)\end{array}$ & $\%$ Disabled & Susceptibility & $\%$ & $\begin{array}{l}\% \text { of population with } \\
\text { any kind of } \\
\text { disabilities, also } \\
\text { people less } 12 \text { and } \\
>65 \text { years }\end{array}$ & $\begin{array}{l}\text { Higher } \% \text {, higher } \\
\text { vulnerability }\end{array}$ \\
\hline $\begin{array}{l}\text { Awareness } \\
\text { and } \\
\text { preparedness }\end{array}$ & $\mathrm{A} / \mathrm{P}$ & Resilience & & $\begin{array}{l}\text { Are the coastal people } \\
\text { aware and prepare for } \\
\text { floods? Did they } \\
\text { experience any floods } \\
\text { in the last } 10 \text { years? }\end{array}$ & $\begin{array}{c}\text { Higher \# of past floods, } \\
\text { more prepare/aware, } \\
\text { lower vulnerability }\end{array}$ \\
\hline Recovery time & RT & Resilience & days & $\begin{array}{l}\text { Amount of time needed } \\
\text { by the city to recover } \\
\text { to a functional } \\
\text { operation after coastal } \\
\text { flood events }\end{array}$ & $\begin{array}{l}\text { The higher amount of } \\
\text { time, the higher } \\
\text { vulnerability }\end{array}$ \\
\hline $\begin{array}{l}\mathrm{km} \text { of } \\
\text { drainage }\end{array}$ & Drain & Resilience & $\mathrm{km}$ & $\begin{array}{l}\mathrm{km} \text { of canalisation in } \\
\text { the city }\end{array}$ & $\begin{array}{l}\text { Higher km, low } \\
\text { vulnerability }\end{array}$ \\
\hline
\end{tabular}

Coastal City Flood Vulnerability Index for Social and Economic Components was expressed as follows:

$$
\begin{gathered}
\mathrm{FVI}_{\text {Social }}=f \frac{\mathrm{CH}, \mathrm{PCL}, \% \text { Disable }}{A / P, S} \\
\mathrm{FVI}_{\text {Economic }}=f \frac{\mathrm{GCP}}{\mathrm{RT}, \text { Drainage }}
\end{gathered}
$$

Explanation of indicators: the indicator "population close to the coastline" is defined as the number of people exposed to coastal hazards. For example, "population living in the flood-prone area along the coast", "growing coastal population" refers to the percentage growth in population of the urban area, which signifies the economic wealth of the urban area. The indicator "awareness/preparedness" was scaled between 1 and 10, where 1 is given for the area where population has no concern with floods and 10 for the urban area 
Table 4 Indicators for the politico-administrative component

\begin{tabular}{|c|c|c|c|c|c|}
\hline Indicators & Abb. & Factor & Unit & Definition & $\begin{array}{l}\text { Functional } \\
\text { relationship with } \\
\text { vulnerability }\end{array}$ \\
\hline $\begin{array}{l}\text { Flood hazard } \\
\text { maps }\end{array}$ & FRP & Susceptibility & - & $\begin{array}{l}\text { Flood hazard mapping is a vital } \\
\text { component for appropriate land use } \\
\text { planning in flood-prone areas }\end{array}$ & $\begin{array}{l}\text { Existence of } \\
\text { those measures, } \\
\text { lower } \\
\text { vulnerability }\end{array}$ \\
\hline $\begin{array}{l}\text { Institutional } \\
\text { organisations }\end{array}$ & $\mathrm{IO}$ & Resilience & \# & Existence of IO & $\begin{array}{c}\text { Higher \#, lower } \\
\text { vulnerability }\end{array}$ \\
\hline $\begin{array}{l}\text { Uncontrolled } \\
\text { planning } \\
\text { zone }\end{array}$ & UP & Exposure & $\%$ & $\begin{array}{l}\% \text { of the surrounding coastal area } \\
\text { (10 km from the shoreline) is } \\
\text { uncontrolled }\end{array}$ & $\begin{array}{l}\text { Higher } \%, \text { higher } \\
\text { vulnerability }\end{array}$ \\
\hline $\begin{array}{l}\text { Flood } \\
\text { protection }\end{array}$ & FP & Resilience & - & $\begin{array}{l}\text { The existence of structural measures } \\
\text { that physically prevent floods from } \\
\text { entering into the city (storage } \\
\text { capacity) }\end{array}$ & $\begin{array}{l}\text { If YES, lower } \\
\text { vulnerability }\end{array}$ \\
\hline
\end{tabular}

where the population has experienced floods for a long time. Therefore, people must aware of the potential for floods in the area, that is, they have trust in institutions to mitigate the harm of floods, they have flood insurances, they understand the consequences and restrictions of their actions towards flood protection, and they are prepared for emergency situations.

The Drainage (D), Recovery Time (RT) and Growing Coastal Population (GCP) indicators belong to the economic component (Eqs. 5 and 7), and they are associated with the economy state of an area as follows:

Drainage indicator represents the length of canals in the area (in kilometres) and belongs to resilience (i.e. is seen in the denominator in Eq. 5). The indicator has an indirect relation with the vulnerability: the longer the kilometres of drainage, the lower the vulnerability. The drainage indicator reflects the economic state of the area: the higher the number of kilometres of drainage, the richer the region.

The RT indicates the amount of time needed by the city to recover to a functional operation after coastal flood events: longer the time, higher the vulnerability. This indicator belongs to the economic component because it reflects the wealth of an area. Richer states recover faster, due to the higher GDP/cap for example. The RT indicator was scaled between 1 and 10, where 1 means that all economic activities are strongly damaged and they may not recover for many years and 10 means that the economic activities of the region are hardly affected by floods, either in the short or in the long term.

The GCP refers to the percentage growth in population in the urban area which shows the economic wealth of the urban area, and therefore belongs to exposure factor (i.e. is seen at the numerator in Eq. 5). The GCP has a direct relation with the vulnerability: higher the GCP, higher the vulnerability. The GCP is an indicator, which reflects the economic state of an area.

Coastal City Flood Vulnerability Index for Politico-Administrative Component was calculated as follows:

$$
\mathrm{FVI}_{\text {Politico-Administrative }}=f \frac{\mathrm{FHM}, \mathrm{UP}}{\mathrm{IO}, \mathrm{FP}}
$$

Total Coastal City Flood Vulnerability Index was calculated as follows: 
Total FVI = Hydro-Geological + Social + Economic + Politico-Administrative

$$
\begin{aligned}
\text { Total FVI }= & \left\{(\mathrm{SLR}, \mathrm{SS}, \# \text { Cyc,FS,RD,Soil,CL })+\left(\frac{\mathrm{CH}, \mathrm{PCL}, \% \text { Disable }}{S, A / P}\right)\right. \\
& \left.+\left(\frac{\mathrm{GCP}}{\mathrm{RT}, \text { Drainage }}\right)+\left(\frac{\mathrm{FHM}, \mathrm{UP}}{\mathrm{IO}, \mathrm{FP}}\right)\right\}
\end{aligned}
$$

The integrated Coastal City Flood Vulnerability Index is a method to combine multiple aspects of a system into one number. On a global perspective, the results will be presented in values between 0 and 1: 1 being the highest vulnerability found in the samples studied and 0 the lowest vulnerability.

\section{Application of the CCFVI methodology in order to assess FVI of different deltaic areas, using FVI tool}

The CCFVI methodology uses a total of 19 indicators. Nine case studies were selected based on city size and different physiographic setting. They are Buenos Aires (Argentina), Calcutta (India), Casablanca (Morocco), Dhaka (Bangladesh), Manila (Philippines), Marseille (France), Osaka (Japan), Shanghai (China) and Rotterdam (the Netherlands). Table 5 shows the indicator values for each component for four of the cities. The nine cities selected are in both developed and developing countries.

\subsection{Data sources}

The following data sources were used to assess the values of the flood vulnerability indicators for each of the cities. The data collection was done via the Internet and so used readily available sources.

1. Casablanca "Academie de l'eau", the website of Environmental Ministry of France and "Gouvernement du Royaume du Morocco", the website of Government of Morocco and the International Federation of Red Cross for floods in Morocco.

2. For Calcutta, various sources were consulted, the Department of Natural Resources, Weather Underground India, Webster et al. (2005), World FactBook (database developed by the CIA with basic information on all the countries in the world), World Bank, UNICEF India, ADB Asian Development Bank, Megaessays (source for highquality essays on a wide range of subjects), Debasri et al. (1995), GIS Development of India, Ministry Water Resources India.

3. For Dhaka: World Bank, HighBeam research, World FactBook were used.

4. For Manila, the website of PAGASA, Philippines Atmospheric, Geophysical and Astronomical Services Administration, the article of Zoleta-Nantes (1999), ICHARM and Connor and Hiroki (2005) were used.

5. Buenos Aires. AIACC, Assessments of Impacts and Adaptations to Climate Change, Academie de l'eau, Bnamericas (the leading source of business information in Latin America) were the sources.

6. For Osaka city: Kawai et al. (2008), Japan River Organisation, Kadoya et al. (1993), MLIT website (Ministry of Land, Industry and Transport), ICHARM.

7. For the city of Marseille, the Academie de l'eau website, Marseille Municipality and the Water Resources eAtlas (an electronic Atlas developed by IUCN, IWMI, Ramsar and WRI) website were used. 


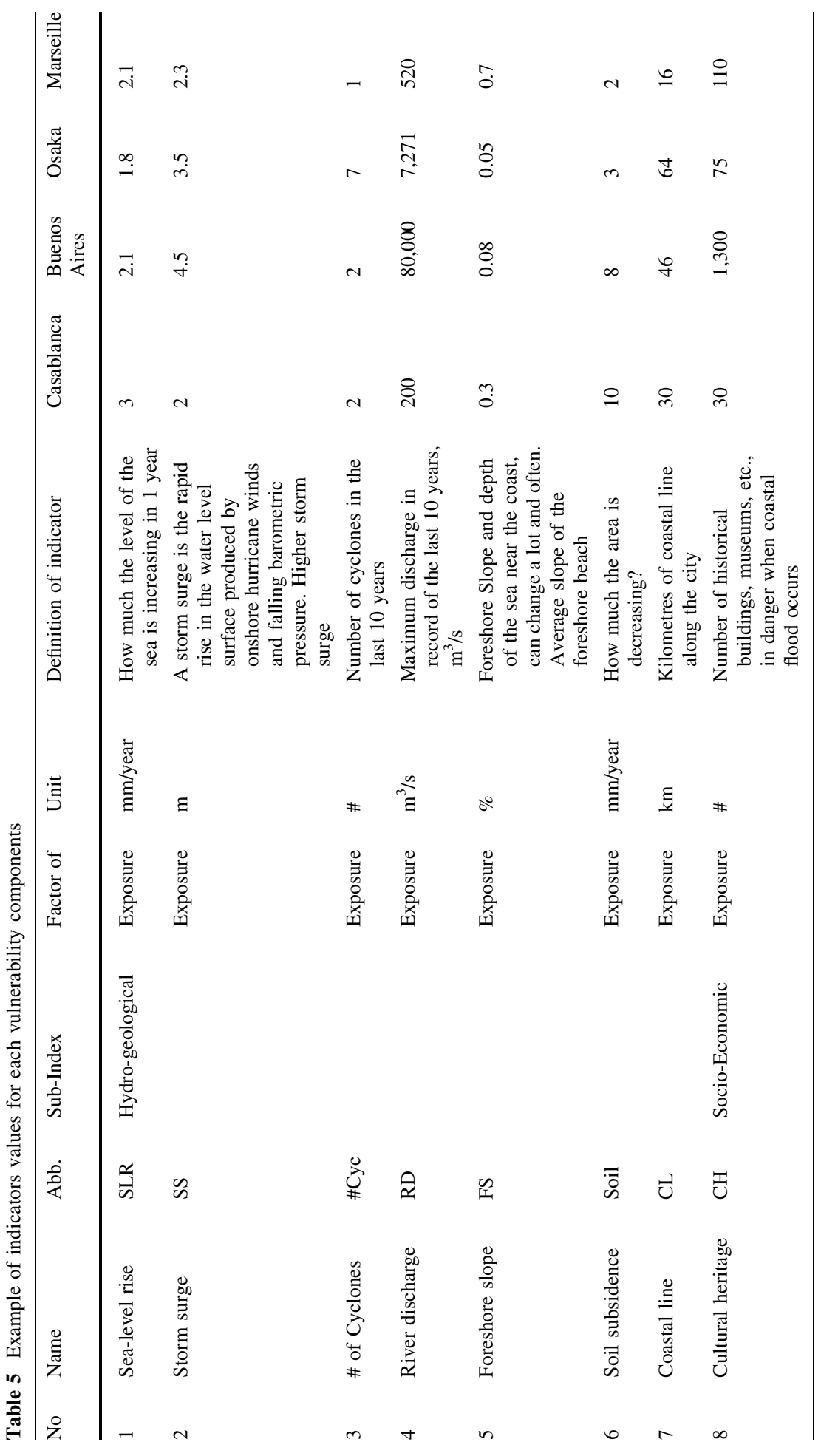




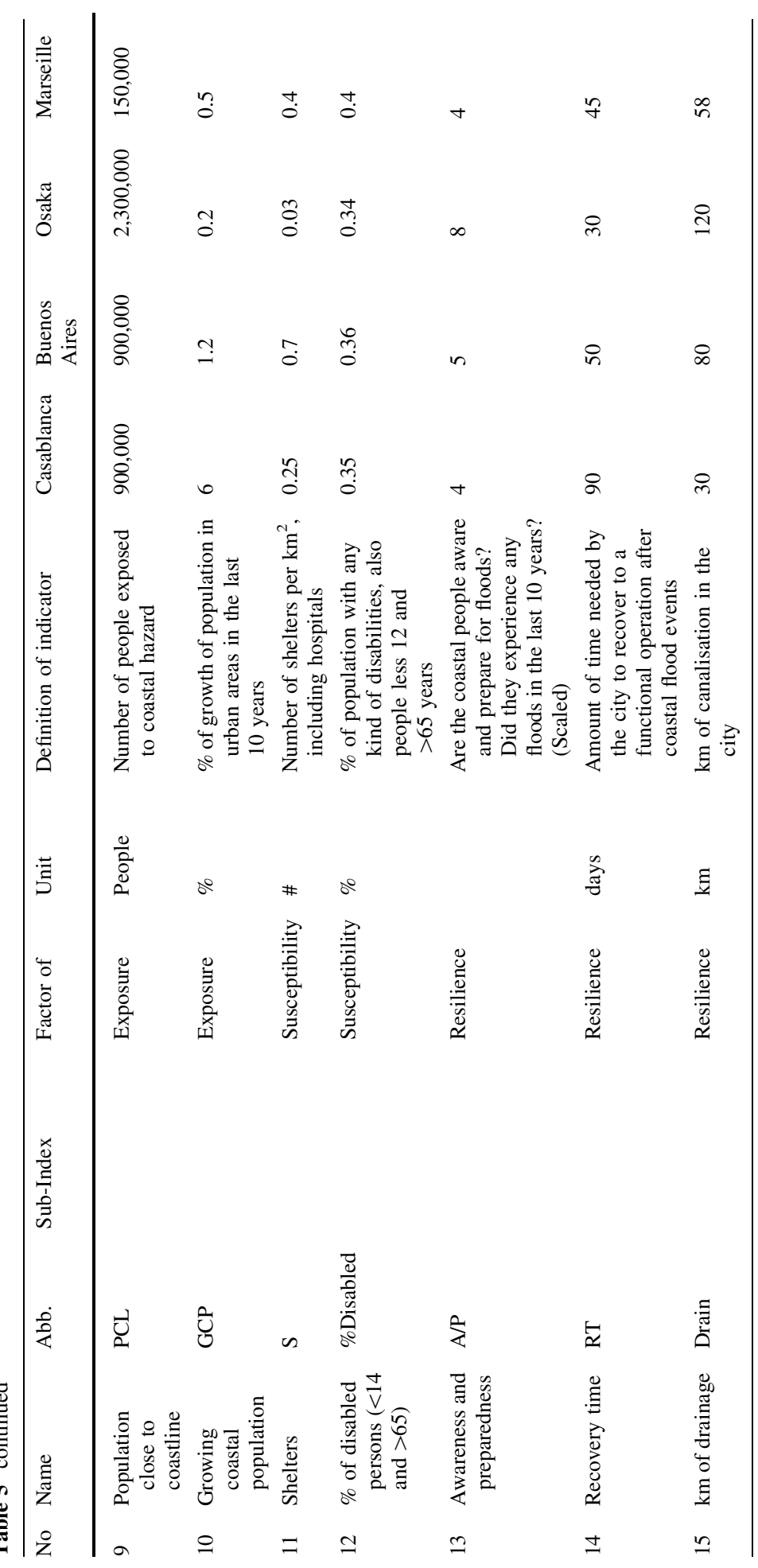




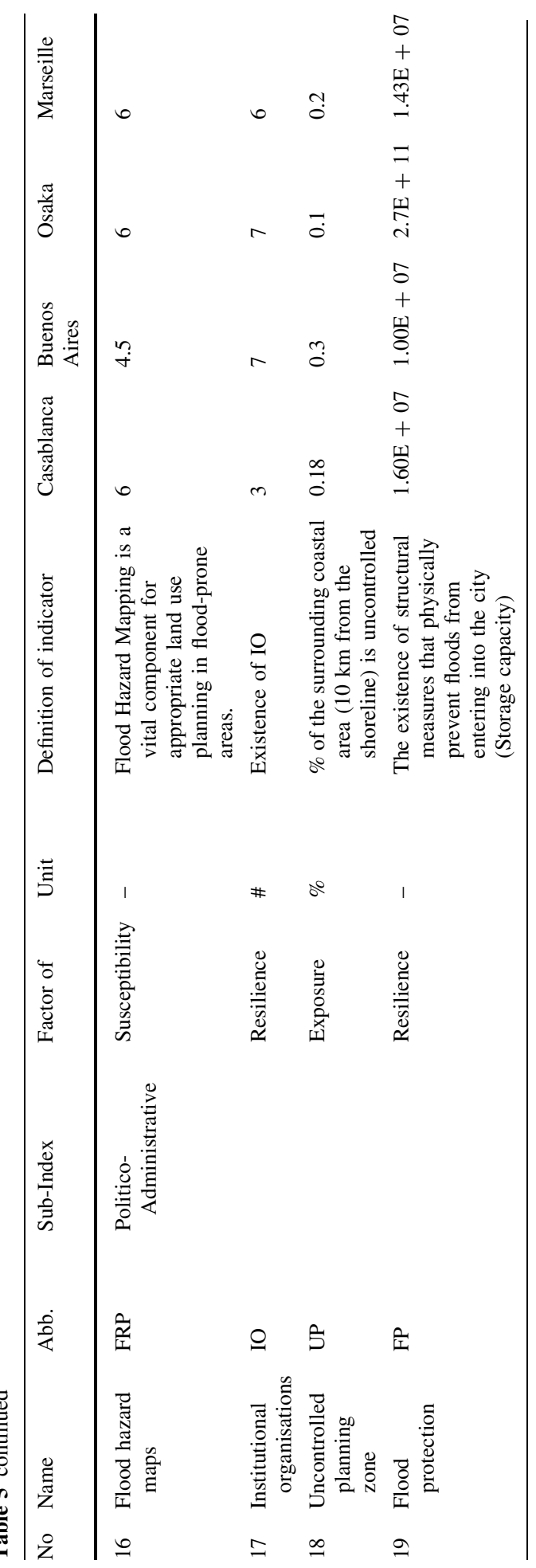


8. For Shanghai, the Yazhi River Committee, UNESCAP data sources were taken into consideration.

9. For Rotterdam: UNESCAP, Walstra (2009), Bijker, (1996), EUROSION (Holland Coast) were used.

The results of the CCFVIs for all components and the total CCFVI are summarised below and easily computed using the FVI tool, unesco-ihe-fvi.org (Balica and Wright 2009) for coastal cities.

\subsection{The hydro-geological component}

The values of the hydro-geological component indicators were used in Eq. 3, described in the section above; the results of the hydro-geological component are shown in Fig. 3. Seven indicators are used to determine the hydro-geological CCFVI values. The indicators all belong to the exposure factor.

When examining the hydro-geological exposure, it can be seen that Shanghai is the most exposed to coastal floods. This is mainly due to its high length of coastline and the high value of river discharge. Following vulnerable city is Manila, largely due to its exposure to tropical cyclones and flooding. The recent tropical storm Typhoon Ketsana in 2009 illustrates this exposure of Manila and the surrounding area to environmental threats. With flood waters reaching nearly $7 \mathrm{~m}$ a.s.l in some city areas (WWF 2009) and hundreds of deaths during this one storm, Manila is highly vulnerable. Dhaka and Calcutta come next largely because of their storm surge, coastal line length and river discharge. Rotterdam city is situated on the fifth place, with a very high soil subsidence and a high Rhine river discharge. The city of Buenos Aires ranks the sixth, with a very high river discharge value but very low amount of kms of coastline, storm surge, number of cyclones. Marseille and Osaka are coming close in the rank as seven and eight. The least vulnerable from all the examples is Casablanca with small number of cyclones in the last 10 years, few kms along the coast and no river discharge. However, this is not implying that the city is not vulnerable to coastal floods. All these cities have already been subjects of coastal floods with loss of life and significant damage costs.

\subsubsection{The social component}

The values of the social component indicators were used in Eq. 4, described above. The results of the social component are shown in Fig. 4. Five indicators, belonging to all factors

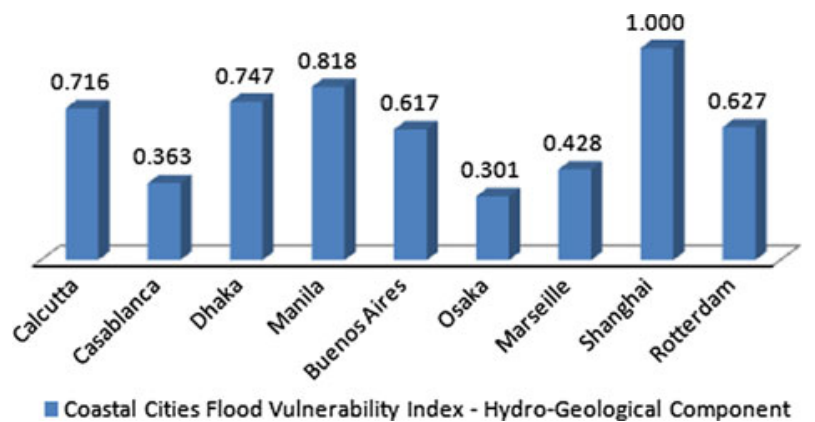

Fig. 3 CCFVI hydro-geological component (exposure to coastal flood) 


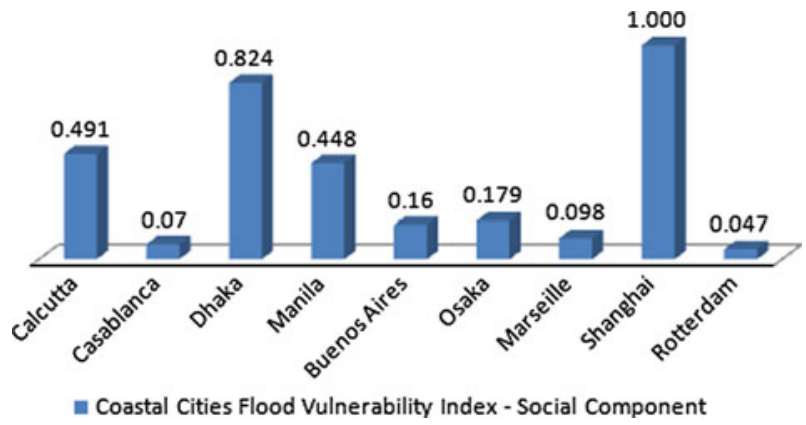

Fig. 4 CCFVI social component

of vulnerability, were used to determine the social CCFVI values. These were population, cultural heritage, shelters, flood cultural behaviour (awareness and preparedness) and \% of disabled population. Using these criteria, Shanghai stands out as the most vulnerable to coastal floods, mainly due to its high number of people living in coastal flood-prone areas, fewer shelters. The second most vulnerable city to coastal floods is Dhaka for similar reasons. Calcutta and Manila are third/fourth most vulnerable, while Osaka and Buenos Aires come next. The City of Rotterdam is ranked the seventh place from the nine cities studied. The population living in coastal area is smaller and has a high social resilience. Marseille and Casablanca are less socially vulnerable to coastal floods.

\subsubsection{The economic component}

Three indicators are used to determine the economic CCFVI values. They are growing coastal population, recovery time after flood event and kms of drainage canal. The results of the economic component are shown in Fig. 5. It can be seen using these criteria that Manila is the most vulnerable economically to coastal floods. The economy of Manila will recover very slow mainly due to the high number of days needed to recover after a flood event and small kms of drainage. The second most economic vulnerable city to coastal floods is Calcutta for similar reasons. Dhaka is the third most vulnerable and Shanghai the fourth, while Casablanca and Buenos Aires come next. Marseille is the seventh vulnerable coastal city from the nine. Rotterdam and Osaka are least vulnerable. Their economy will recover fast, due to large amount of investment in counter measures and high GDP/cap; the

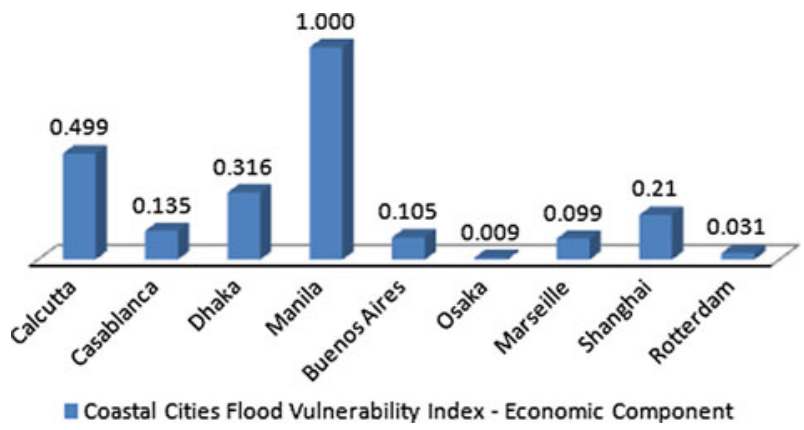

Fig. 5 CCFVI economic component 


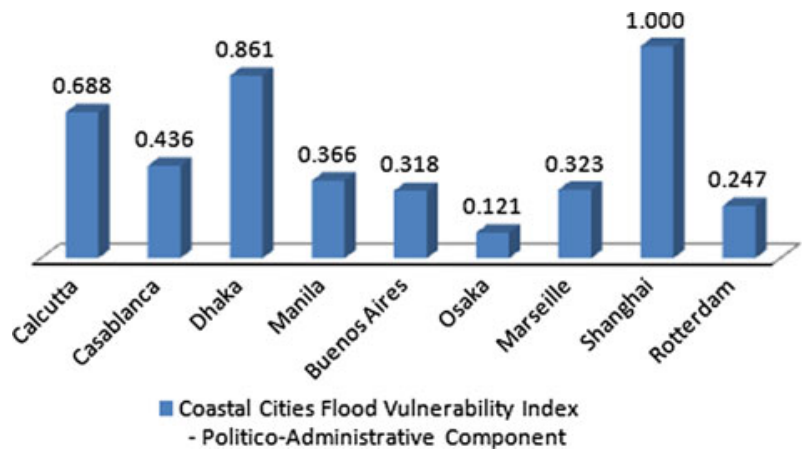

Fig. 6 CCFVI politico-administrative component

cities show a small exposure to natural hazards, but they have large number of kms of drainage.

\subsubsection{The politico-administrative component}

The politico-administrative component (PAC) shows the involvement of institutional organisations in the flood management process. As seen in Fig. 6, the most vulnerable politico-administrative is Shanghai, having small politico-administrative resilience $(0.15$, this is the value of PAC's resilience), small storage capacity and a small number of institutional organisations as well as being highly exposed to flood hazards; the uncontrolled planning zone indicator is high $0.6 \%$ compared with the other cases where it oscillates around 0.2. Dhaka and Calcutta rank as having the second and third politicoadministrative coastal flood vulnerability, 0.25 and 0.29 resilience values, respectively, with smaller number of institutional organisations and little flood protection. The cities Marseille, Rotterdam and Osaka lie in developed countries (UN classification) and have the lowest administrative vulnerability to coastal floods; these cities are the least exposed from PAC.

\subsubsection{The Overall Coastal City Flood Vulnerability Index}

Of the nine cities examined, Shanghai, in China, is most vulnerable to coastal floods overall. Exposed to hydro-geological factors such as storm surge and sea-level rise, the city faces a high river discharge and serious land subsidence (it results in lowering the standard of coastal flood preventing establishments and increases the risk of natural disasters of typhoon, rainstorm, flood). The indicator soil subsidence is considered during the whole study as an indicator that belongs to the hydro-geological component. From the overall results can be seen that land subsidence indicator influences among other the ranking. From a social perspective, the population close to the coastline is high, people experience floods, but the city does not have high resilience and the number of shelters is low compared to the population density. Dhaka, which sits just metres above current sea levels, is regularly impacted by tropical cyclones and flooding and has very little resilience. Manila in the Philippines and Calcutta in India are also highly vulnerable cities and tie for the third rank, largely because of the size of the cities, degree of exposure (both experience frequent flooding) and relatively low resilience. Buenos Aires and Casablanca are fourth/fifth, 


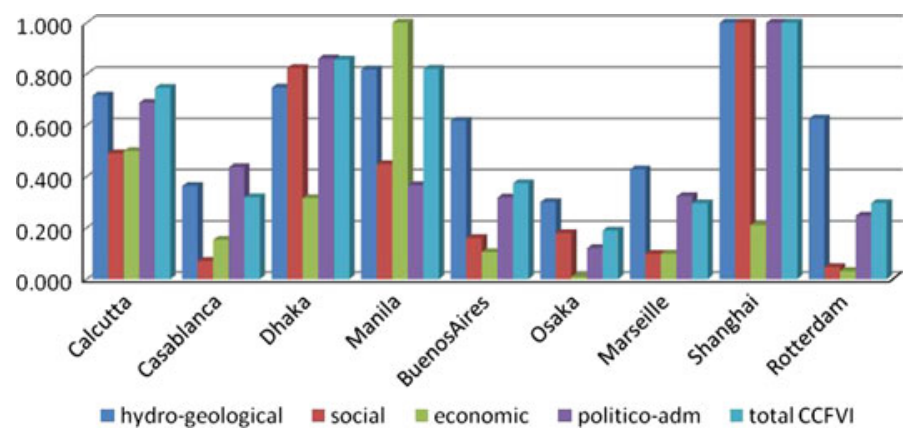

Fig. 7 Overall Coastal City Flood Vulnerability Index

largely because Casablanca is economically vulnerable to floods and has very little flood protection, while Buenos Aires has very low resilience and fewer institutional organisations. Marseille in France and Rotterdam in the Netherlands have equally low vulnerability, mostly because both have slightly more resilience than the other cities, even though the hydro-geological indicators are still significant. Osaka is the least vulnerable city out of nine; the city is the least vulnerable hydro-geological and politico-administrative terms (Fig. 7).

The advantage of the index is that one can clearly compare vulnerabilities of cities. Poor cities may wish to compare their position relative to rich cities. The CCFVI can be used as a network of knowledge to learn from each other and to increase the resilience of delta cities worldwide through the knowledge given by delta alliances. Publishing the component parts of the Coastal City Flood Vulnerability Index can show where progress needs to be prioritised. The focus of publishing the article is rather hydro-geological and socioeconomic than political.

The CCFVI model can give a simplified way of characterising what in reality is a very complex system. Such results will help to give an indication of whether a system is resilient, susceptible or exposed to flooding risks and help identify which measures would reap the best return on investment under a changing climate and population and development expansion. The important point is that such a model is used as one tool among others within the whole process of deciding on a roadmap for flood assessment.

On the other hand, the method has weaknesses: the index-based technique presents vulnerability over a short period of time. Currently, the FVI method is not capable of encapsulating temporal changes; the CCFVI model is a simplification of reality and its application should be compensated with thorough knowledge and expertise-based analysis. The difficulties that the quantification of social and political-administrative indicators, as well as availability of other indicators, poses to the calculation may constitute a considerable weakness of the model.

Another potential weakness is the soundness of it underlying assumptions. For the CCFVI to be accepted by a wide range of stakeholders, the underlying assumptions for each indicator would need to be explained. The danger in using these types of indices is that stakeholders feel a loss of control and may feel it is just a black box churning out results. A way to overcome this is to involve stakeholders in the developments and in the weighting of the indicators.

It is also a simplified version of reality without capturing the interconnectedness of several indicators and potentially ignoring important local specificities. 


\section{Climate change impacts on CCFVI indicators and consequently on CCFVI}

An indicator-based methodology such as the one outlined here can be used to study the impact of future changes on vulnerability. The indicators express the natural resources, the people and the economic state of the city. Therefore, it is very important to know the impacts on the people, cities, natural resources, via the use of these indicators.

In particular, it can be used to study the impact of climate change and this is presented below. In order to do this, a number of assumptions about the impact of climate change on the relevant indicators have to be made.

The following hydro-geological indicators reflecting climate change projections were chosen: sea-level rise (Gornitz 2001), increasing number of cyclones, higher river discharges and increased storm surge and soil subsidence. The impact of climate change to the social component is reflected in the following indicators: population close to coastline and awareness/preparedness. The indicator "Population close to coastline (UNFPA 2011a)" will be affected by climate change owing to high population areas that are presently concentrated near the coastline (OCDE 2007; Jian 2008); if population growth will increase, the evacuation of vulnerable populations living in these high-risk areas during coastal floods will pose serious problems.

Climate change will have an impact on the awareness/preparedness indicator. UNEP (2006) presents the importance of communicating with the general public and engaging stakeholders about climate change. Already, educational and public awareness programmes on climate change were developed and implemented (Russia, Kenya, Albania, Cambodia, etc.)

Public awareness aims at early results and is often pursued via the media and outreach campaigns. It is also pursued via education at a more profound, long-term change in habits, particularly among the young. NGOs and journalists can be helpful allies in promoting climate change awareness because of their role as intermediaries with their own widespread networks for outreach. Climate change should worry everybody, but in truth some people will feel more concerned than others because they face particular risks (coastal flooding).

In the present study, we assume that the economic component will be impacted by climate change only by one indicator, growing coastal population.

Rapid growing population is occurring in coastal cities all over the world. Severe flooding regularly destroys coastal regions, particularly when storm surges and high river flows occur simultaneously. Large coastal cities are particularly at risk from rising sea levels, storms and storm surges, and other aspects of climate change (Fuchs 2010; Glade 2003; Harley et al. 2006). The densely populated deltas and other low-lying coastal cities are recognised in the IPCC FAR, 2007 as "key societal hotspots of coastal vulnerability" with lots of people potentially affected.

Only recently, local governments and the international development community have seriously begun to consider the implications of climate change on rapidly growing coastal populations and infrastructure. UNEP (2006) and IPCC (2007a, b) and their partners initiate programmes to assist coordinated action among scientists, policymakers and the public to support impact and vulnerability assessments, awareness raising about climate change risks and integration of scientific information about impacts, vulnerabilities and adaptation into planning and policy for the affected areas.

It is assumed that the politico-administrative component will not change under climate change impacts. As seen, the political-administrative component comprises four indicators: Flood Hazard Maps, Institutional Organisations, Uncontrolled Planning Zone and Flood 
Protection. Each of these indicators expresses somehow the political-administrative situation of a coastal area. None of them refers directly to politicians, but to their decisions on investments, etc. Based on the lack of quantification of the relevant indicators by 2100 , this component was not analysed. As explained, climate change is one of the major drivers of discussions on behaviour and adaptation measures.

\subsection{Scenarios of sea-level rise, now: 2100 (UNEP 1995; IPCC 2007a, b)}

Based on the ranges in the estimate of climate sensitivity and ice melt parameters, and the full set of IS92 emission scenarios, the models predict an increase in global mean sea level of between 13 and $94 \mathrm{~cm}$ and also an increase in soil subsidency between 1,400 and $34,000 \mathrm{~km}^{2}$ (horizontal) for the selected case studies. Webster et al. (2005), IPCC (2007a, b) evaluated the increased number of the cyclones and increased number of storm surge, using numerical simulation, and predicted that by 2100 the number and the intensity of cyclones will increase between 10 and $20 \%$. The river discharges will also increase (Jian 2008), and here it is assumed, based on the IPCC report (IPCC 2007a, b), that the river discharge will double for all case studies in the worst-case scenario. ${ }^{1}$

Two scenarios were used for the hydro-geological component (according to Fig. 3). The first scenario is termed the "best-case scenario" and assumes that the indicators impacted by climate change increase by $20-50 \%$ dependent on city location and taking into consideration the values assumed in the literature. In the second scenario, termed the "worstcase scenario", the indicators are assumed to have the highest values found in the literature for each case study. For some cities such as Casablanca and Marseille, they were assumed to be doubled.

By the 2100, the most vulnerable from the nine cities in terms of hydro-geological exposure can be seen from Fig. 8.

Again, for the social and economic component, we adopt two scenarios "best-case scenario" and "worst-case scenario". For the best-case scenario, it is supposed that the population close to coastal line (social)/growing coastal population (economic) is increasing from 1.1 to 2, depending on values found for those indicators in the Jian (2008)/ SRES scenarios for the studied cases. For the worst-case scenario, we assume that the population close to coastal line (social)/growing coastal population (economic) will triple based on figures from the OCDE (2007). The results can be seen in Figs. 9 and 10.

It can be noted that the component of vulnerability most impacted by climate change is the economic component with high increases in the 2100 results: $6.5-177$ times the 2009 values. However, due to low 2009 values for economic component, the overall 2100 raw results will be influenced in the same way for all the components (see Fig. 10).

By 2100, it can be seen in Fig. 11 that the city of Shanghai and Dhaka will remain the most vulnerable to coastal floods, followed tied by Manila and Calcutta, Casablanca, Rotterdam. Buenos Aires and Marseille remain in the lower positions of the nine. Osaka is the city least vulnerable to floods from the selected case studies, very high protection level, high number of kms of dikes.

Also by 2100 , it can be seen that the vulnerability of Manila will increase by 2.0, followed by Osaka (1.7), Casablanca (1.5), Rotterdam and Calcutta (1.4), the cities of Dhaka and Marseille will increase by 1.3, Shanghai (1.27) and Buenos Aires (1.2) will increase the least from the nine cities studied. The numbers represent the ratio between

1 Of course, this may well not be the case, as for example more detailed studies state that for Rotterdam, the Rhine river discharge is likely to increase by 2100 from 16,000 to $18,000 \mathrm{~m}^{3} / \mathrm{s}$ (Deltacommissie 2008). 


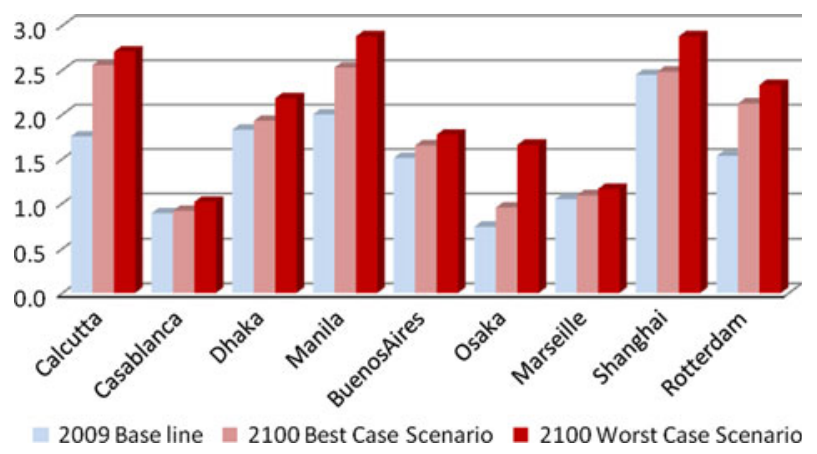

Fig. 8 Climate change impacts scenarios on hydro-geological component of CCFVI

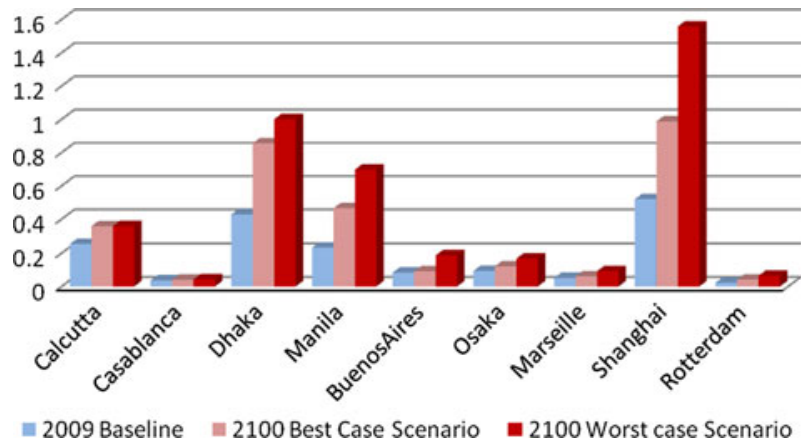

Fig. 9 Climate change impacts scenarios on the social component of CCFVI

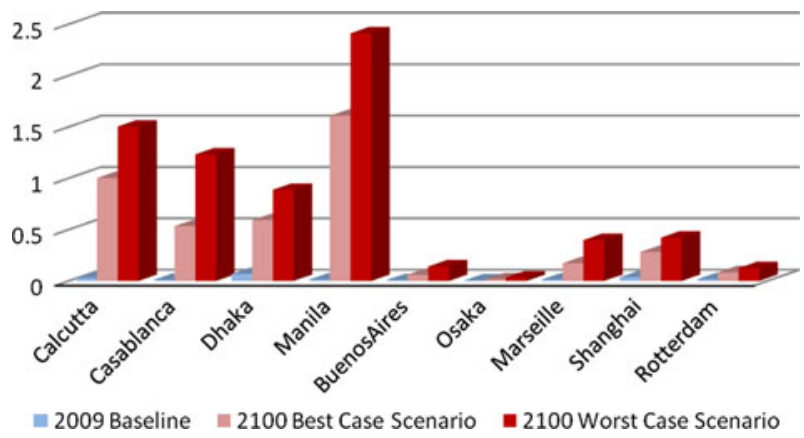

Fig. 10 Climate change impacts scenarios on the economic component of CCFVI

worst-case scenario and baseline. The position of the city in the rank will not change directly with the increase.

The baseline 2009 results show the city's vulnerability from 2009. In order to see which component is most vulnerable to flooding for each coastal city with the 2100 worst-case scenario, the values are shown without normalisation. The difference between the raw CCFVI results of the two cases was computed and the variations are presented in Fig. 12. Here, it can clearly be seen which cities are most impacted with climate change in relation 


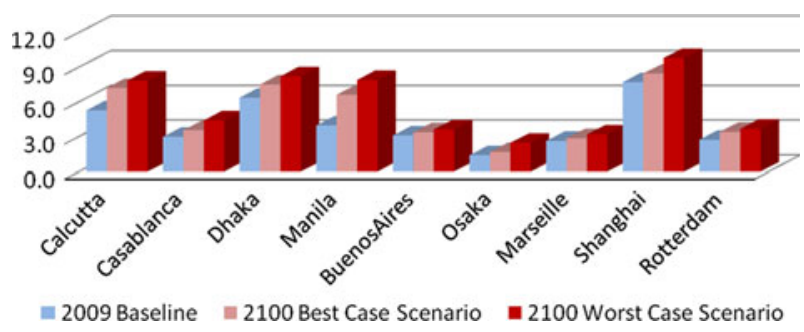

Fig. 11 Comparison between the total CCFVIs after considering the two scenarios

Fig. 12 Difference in climate change impacts scenarios to Coastal City Flood Vulnerability

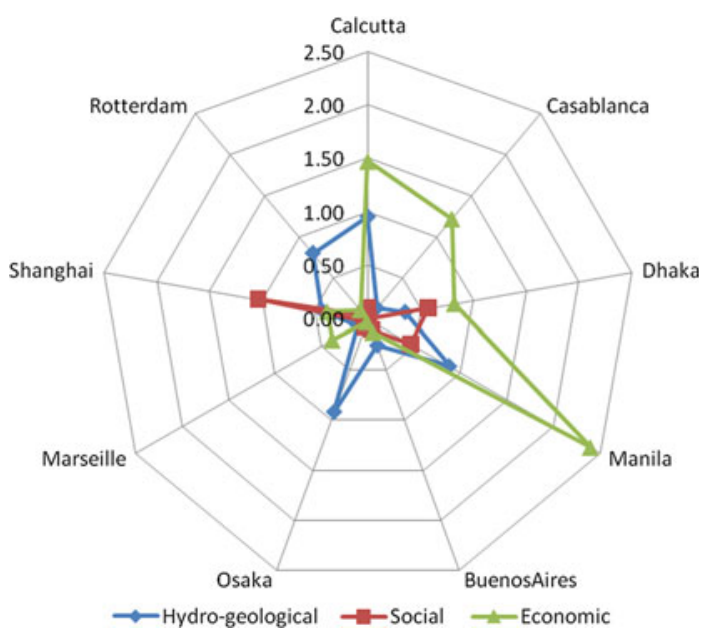

to each component. Manila has the most variations, which reflects the fact that the city is characterised by economic extremes with a considerable disparity between the wealthy few and the large number of people below the poverty line. Reportedly, $97 \%$ of the total GDP in the Philippines is controlled by $15 \%$ of the population (Yusuf and Francisco 2009). With the Growing Coastal Population indicator increasing by 2100, Manila city will be even more economically vulnerable to coastal floods, which explains the high economic vulnerability.

The study also provides interesting insights into future (2100) total flood vulnerability on a coastal city scale (Total CCFVI); a ranking of those cities can be seen in Table 6. By 2100 worst-case scenario, the most vulnerable city to coastal floods will remain Shanghai, followed very close by Dhaka and least vulnerable Marseille and Osaka, taking into account that no adaptation measures are included into the analysis.

\section{Discussion on managing coastal cities throughout CCFVI tool (http://unesco-ihe-fvi.org)}

There can be no analysis or assessment of flood and risk management and adaptation measures without, first, understanding correctly the concept of vulnerability. Vulnerability is an analysing element of exposure, susceptibility and resilience of any coastal system at hazard. Vulnerability index captures a zooming in view, which helps in assessing aspects 
Table 6 Total FVI, ranking of coastal cities for different scenarios

\begin{tabular}{llll}
\hline City & $\begin{array}{l}2009 \\
\text { Baseline }\end{array}$ & $\begin{array}{l}\text { 2100 Best } \\
\text { scenario }\end{array}$ & $\begin{array}{l}2100 \text { Worst } \\
\text { scenario }\end{array}$ \\
\hline Coastal cities total & FVI ranking & & \\
Calcutta & 3 & 3 & 4 \\
Casablanca & 6 & 5 & 5 \\
Dhaka & 2 & 2 & 2 \\
Manila & 4 & 4 & 3 \\
Buenos Aires & 5 & 7 & 7 \\
Osaka & 9 & 9 & 9 \\
Marseille & 8 & 8 & 8 \\
Shanghai & 1 & 1 & 1 \\
Rotterdam & 7 & 6 & 6 \\
\hline
\end{tabular}

that might have been neglected by traditional approach to assess or analyse risk so far. As another argument to assess and index vulnerability is the requirements of the European Floods Directive 2007/60/EC and the "Hyogo Framework for Action 2005-2015". Therefore, not only politicians, but also decision-makers need such indices, the standardised vulnerability indices are helping in assessing and monitoring the "elements at risk" (Merz et al. 2007). This need, the indices, involves a range of subjective decisions, the choice of indicators for example, but if the vulnerability concept is well defined and clarified, the evaluation and interpretation of composite indices will bring us the understanding of where to mitigate risk and where to focus investments. Still there is no standardised way to measure vulnerability (Bohle et al. 1994), and the measurement depends on each hazard that occurs, its frequency and its intensity.

The methodology used in this article is based on sets of indicators for different vulnerability factors and coastal system components, focusing on coastal floods. Selected indicators (19) have been used to quantify flood vulnerability of coastal cities. In the CCFVI approach, the indicators were normalised separately using predefined minimum and maximum values to facilitate easily comparison between case studies and to provide one single and comparable value. The final Coastal City Flood Vulnerability component values are therefore between 0 and 1 . However, in order to present consistent final results of climate change impact scenarios, the raw results are shown.

Since the methodology is based on indicators, its main weakness is the accuracy of the data on which it is based. For the results to be valid, all data must be derived from reliable sources (see Sect. 3.3). This approach allows for relative comparisons to be made between urban areas irrespective of uncertainties. In this way, proposed measures can be prioritised for urban areas that are at greatest risk. Uncertainty is not removed, but is integrated into the assessment. While a level of uncertainty is inherent in CCFVI, its use in operational flood risk management is useful for policy and decision-makers in terms of prioritising investments and formulating adaptation plans. It also offers a more transparent means of prioritising, which is inevitably a highly political process. It may also be considered a means to steer flood management policy in a more sustainable direction. As individual information is lost in the aggregation process, it needs to be retrieved by a more in-depth analysis of each process in order to design policies and their implementation measures. For example, the magnitude of impact of different factors and of each indicator on the CCFVI needs to be well understood. 
It is worth underlining that the CCFVI is a flexible tool: it can be used to create different "scenarios" by changing one or more indicators and can be tailored on different situations and areas, since the principle "one size fits all" cannot be applied to vulnerabilities present in complex and dynamic realities.

Another weakness of the method, the unevenness of the indicators, has two main consequences. Firstly, the indices calculated by the model are distorted. Components with more indicators are more reliable than components with few indicators on this level. Components with few or no indicators are not well represented. Furthermore, the components with few indicators are less reliable. This is due to the occurrence that a large variation in one variable has a larger influence on the calculated index. The second main consequence of the unequal distribution of indicators is on the feasibility of calculating the index of a certain component. If more indicators are available, the user of the model can choose the indicators according to the information that is most readily available making the model more feasible.

To improve the model, the number of indicators would need to be increased in the areas with fewer indicators at the moment. Preferably, these indicators would coincide with information that most governing bodies are already collecting in order to increase the ease of use of the model.

The CCFVI can be used as an effective tool to assist decision-makers in evaluating the impacts of different scenarios. A quantification of coastal flood vulnerability is the CCFVI, a non-structural measure (more in the interest of general public, policy and decisionmakers, re/insuring companies), the index can be incorporated into the Disaster Risk Reduction Strategy.

The CCFVI can also be used as a toolkit to assess and manage the coastal flood vulnerability and this way to facilitate adaptation and coping capacities. The CCFVI methodology is at the base of a network of knowledge, among the flood vulnerability index methodology (unesco-ihe-fvi.org), which is an automated calculation of a CCFVI implemented through a web management interface (PHP) that enhances the ability of decisionmakers to strategically guide investment (Balica and Wright 2009). The network of knowledge can be used between different institutions, universities and non-governmental organisations with the purpose to encourage collaboration between the members of the network on managing coastal flood vulnerability information and also promoting further studies on flood risk assessment at smaller scales. The CCFVI can help in converting knowledge into actions: to assess/index the coastal flood vulnerability in different regions of the world, but also in less well-served ones, data scarce areas, by following an integrated approach; raise coastal flood vulnerability awareness; save lives, reduce economic, environmental losses; and distribute the financial burden better.

Other future developments work in two ways. Firstly, increasing populations are likely to increase the vulnerability to flooding owing to increased inhabitation of flood-prone areas (Saalmueller, n.d.). Populations are likely to expand into areas that are currently covered by natural vegetation (Marcoux 2000; DeFries et al. 2010) and the densities of urban environments already within flood plains and coastal areas are likely to increase (UNFPA 2011b).

On the other hand, the vulnerability could decrease due to development which could lower susceptibility indicators such as increased awareness and education (IIASA 2008). Other resilience indicators could also improve due to public investments in (protective) infrastructure and increased institutional capacity as countries develop. 


\section{Conclusions}

The conclusions of this work cover three aspects:

- CCFVI methodology and use The use of the CCFVI can make inhabitants and governments aware of vulnerability in their area. With the CCFVI, the impacts can be predicted in different scenarios. In this way, it helps policymakers and water authorities to define what measurements should be taken. CCFVI is a powerful tool for mapping of vulnerable areas within the cities. Thus, the correct use of CCFVI can help policymakers and urban planners in making decisions with regard to development in specific areas and possible funding allocation for adaptation and reduction of flood vulnerability in urban areas. The continuous monitoring of the CCFVI for particular urban areas may also show a trend in the development of the area over time and will also give tangible information for preparation in case of flooding. Thus, the CCFVI is necessary, but not sufficient for decision-making. The CCFVI has to be used in combination with other decision-making tools, which include participatory methods with the population of areas identified as vulnerable and expert judgment. The CCFVI can be used with a team of multidisciplinary thematic specialists and representatives of society, all knowledgeable on the site and specifically on a smaller geographical unit, to discuss the most relevant factors explaining exposure, and especially susceptibility and resilience.

- CCFVI baseline results In comparing the cities, Shanghai came out as the most vulnerable to coastal floods. Rotterdam (the Netherlands) and Osaka (Japan) were the least vulnerable to floods. The poorest cities have a very low resilience to floods, are the most exposed socially and have weak institutional organisations.

- Climate change impacts on the CCFVI Climate change is expected to impact the urban coastal delta in various and diverse ways. The hydro-geological component is clearly one of these by definition. However, other components are also affected. The social component shows that the social vulnerability to floods of Shanghai, Dhaka and Manila will double by 2100 . The population close to the coastline and the number of cultural heritages exposed to floods will increase, so there is an urgent need for action towards adaptation measures by raising the anticipatory mentality of local population. The third component affected is the economic component which is more sensitive. By 2100 , the economic vulnerability of the delta cities will increase drastically. Actions must be undertaken to protect them in order to reduce their vulnerability to floods. Collaboration between delta cities' administrations, multiple stakeholders and organisations at international level (delta alliances) has to be undertaken to support the most vulnerable areas and to learn from each other. The use of CCFVI and climate change scenarios offers the opportunity to get a broad overview on components affected and on possible adaptation options that could be applied, directing resources at more in-depth investigation of the most promising adaptation strategies. At a later stage, it can also serve to evaluate the effectiveness of adaptation measures.

Acknowledgments The first author acknowledges support from the UNESCO-IHE Institute for Water Education, the Huygens Programme of the Government of the Netherlands and Rijkwaterstaat. The help and support provided by Dr Rosh Ranasinghe (TU Delft and UNESCO-IHE) is highly appreciated. We would like to thank the anonymous reviewers for their comments that helped improve the manuscript. 
Open Access This article is distributed under the terms of the Creative Commons Attribution License which permits any use, distribution, and reproduction in any medium, provided the original author(s) and the source are credited.

\section{References}

Abuodha P, Woodroffe CD (2007) Assessing vulnerability of coasts to climate change: a review of approaches and their application to the Australian coast. In: Woodroffe CD, Bruce E, Puotinen M, Furness RA (eds) GIS for the coastal zone: a selection of papers from CoastGIS 2006. Australian National Centre for Ocean Resources and Security University of Wollongong, Wollongong, p 458

Adger NW (2006) Vulnerability. Global Environmental Change 16:268-281

Adger WN, Vincent K (2005) Uncertainty in adaptive capacity, C.R. Geo-science 337:399-410

Adriaanse A (1993) Environmental policy performance indicators: a study on the development of indicators of environmental policy in the Netherlands. SDU Publishers, Amsterdam

Baarse G (1995) Development of an Operational Tool for Global Vulnerability Assessment (GVA): update of the number of people at risk due to sea-level rise and increased flood probabilities. CZM-Centre Publication No. 3, Ministry of Transport, Public Works and Water Management, The Hague

Balica SF, Wright NG (2009) A network of knowledge on applying an indicator-based methodology for minimizing flood vulnerability. Hydrol Process 23(20):2983-2986

Balica SF, Wright NG (2010) Reducing the complexity of Flood Vulnerability Index. Environ Hazard J (EHJ) 9(4):321-339, ISSN 1747-7891

Balica SF, Douben N, Wright NG (2009) Flood vulnerability indices at varying spatial scales. Water Sci Technol J 60(10):2571-2580, ISSN 0273-1223

Berkes F, Folke C (eds) (1998) Linking social and ecological systems: management practices and social mechanisms for building resilience. Cambridge University Press, New York

Bijker EW (1996) History and heritage in coastal engineering in the Netherlands. In Kraus C (ed). New York, pp 390-412

Bijlsma L, Ehler CN, Klein RJT, Kulshrestha SM, McLean RF, Mimura N, Nicholls RJ, Nurse LA, Perez Nieto H, Stakhiv EZ, Turner RK, Warrick RA (1995) Coastal zones and small islands. Climate Change. 1995. Impacts, adaptations and mitigation of climate change: scientific-technical analyses. Cambridge University Press, Cambridge, pp 289-324

Blaikie P, Cannon T, Davis I, Wisner B (1994) At risk: natural hazards, people's vulnerability and disasters. Routledge, London

Bohle HG, Downing TE, Watts MJ (1994) Climate change and social vulnerability: toward a sociology and geography of food insecurity. Global Environ Change 4(1):37-48

Boruff BJ, Emrich C, Cutter SL (2005) Erosion hazard vulnerability of US coastal counties. J Coast Res 21:932-942

Briguglio L (1992) Preliminary study on the construction of an index for ranking countries according to their economic vulnerability, UNCTAD/LDC/Misc.4 1992

Briguglio L (1993) The economic vulnerabilities of small island developing states study commissioned by CARICOM for the regional technical meeting of the global conference on the sustainable development of small island developing states, Port of Spain, Trinidad and Tobago

Briguglio L (1995) Small Island States and their Economic Vulnerabilities. World Dev 23(9):1615-1632

Briguglio L (1997) Alternative economic vulnerability indices for developing countries. Report prepared for the Expert Group on Vulnerability Index, United Nations Department of Economic and Social AffairsUN(DESA)

Briguglio L (2003) Methodological and practical considerations for constructing Socio130 economic indicators to evaluate disaster risk. Institute of Environmental Studies, University of Colombia, Manizales, Colombia, Programme on Information and Indicators for Risk Management, IADB-ECLAC-IDEA

Brooks N, Nicholls R, Hall J (2006) Sea level rise: coastal impacts and responses. Norwich WBGU ISBN 3-936191-13-1 Berlin

Cendrero A, Fischer DW (1997) A procedure for assessing the environmental quality of coastal areas for planning and management. J Coast Res 13:732-744

Connor RF, Hiroki K (2005) Development of a method for assessing flood vulnerability. Water Sci Technol 51(5):61-67

Cooper JAG, Navas F (2004) Natural bathymetric change as a control on century-scale shoreline behaviour. Geology 32:513-516 
Covich AP (1993) Water and ecosystems. In: Gleick PH (ed) Water in crisis: a guide to the world's freshwater resources. Oxford University Press, Oxford

Cowell PJ, Stive MJF, Niedoroda AW, De Vriend HJ, Swift DJP, Kaminsky GM, Capobianco M (2003a) The coastal tract. Part 1: a conceptual approach to aggregated modelling of low-order coastal change. J Coast Res 19:812-827

Cowell PJ, Stive MJF, Niedoroda AW, Swift DJP, DeVriend HJ, Buijsman MC, Nicholls RJ, Roy PS et al (2003b) The coastal tract. Part 2: applications of aggregated modelling of lower-order coastal change. J Coast Res 19:828-848

CRED CRUNCH (2010) Disaster data. A balanced perspective, issue 21, August 2010, Centre for Research on the Epidemiology and Disasters, Universite Catholique de Louvain as seen on 9th September 2010 on http://www.cred.be/sites/default/files/CredCrunch21.pdf

Crooks S (2004) The effect of sea-level rise on coastal geomorphology. Ibis 146:18-20

Cutter SL, Boruff BJ, Shirley WL (2003) Social vulnerability to environmental hazards. Soc Sci Q 84(2):242-261

Dal Cin R, Simeoni U (1989) Coastal zoning and vulnerability: application to the Middle Adriatic (Italy). Coastal Zone'89 3:98-110

Dasgupta S, Laplante B, Meisner C, Wheeler D, Jianping Y (2007) The impact of sea level rise on developing countries: a comparative analysis. Policy research working paper, World Bank, WPS4136

Debasri R, Sandip M, Belaram B (1995) Man's influence on freshwater ecosystems and water use. In: Proceedings of a Boulder Symposium IAHS no 230, pp 95-100

DeFries RS, Rudel T, Uriarte M, Hansen M (2010) Deforestation driven by urban population growth and agricultural trade in the twenty-first century. Nature Geosci [Online] 3, Available at: http://www.nature.com/ngeo/journal/v3/n3/full/ngeo756.html [Accessed 16 January 2012]

Deltacommissie (2008) Working together with water-a living land builds for its future-findings of the Deltacommissie 2008. Rotterdam, p 117

Di Mauro C (2006) Regional vulnerability map for supporting policy definitions and implementations. ARMONIA conference "multi-hazards: challenges for risk assessment, mapping and management", Barcelona

Douben N (2006) Characteristics of river floods and flooding: a global overview, 1985-2003. Irrigation Drainage 55:S9-S21 (published online in Wiley InterScience)

du Gommes R, Guerny J, Nachtergaele F, Brinkman R (1997) Potential impacts of sea-level rise on populations and agriculture. FAO, Rome

EC-JRC (2005) Climate change and European water dimension. EU Report No. 21553, Steven J. Eisenreich

Ericson JP, Vorosmarty CJ, Dingman SL, Dingman LG, Meybeck M (2006) Effective sea-level rise and deltas: causes of change and human dimension implications. Global Planet Change 50:63-82

European Parliament and Council of the European Communities (2007) Directive on the assessment and management of flood risks (2007/60/EC). Official J L288/27-34

Fekete A (2009) Validation of a social vulnerability index in context to river-floods in Germany. Nat Hazards Earth Syst Sci 9:393-403. http://www.nat-hazards-earthsystsci.net/9/393/2009/

Fenster MS, Dolan R (1996) Assessing the impact of tidal inlets on adjacent barrier island shorelines. J Coast Res 12:294-310

Fuchs P (2010) Asia's coastal cities in an age of climate change, analysis from East-West Center, No. 96, July 2010, as seen on: http://www.eastwestcenter.org/fileadmin/stored/pdfs/api096.pdf, on 19th of January, 2012

Fuchs S, Kuhlicke C, Meyer V (2011) Editorial for the special issue: vulnerability to natural hazards-the challenge of integration. Natural Hazards. doi:10.1007/s11069-011-9825-5 (published online 17th of May 2011)

Glade T (2003) Vulnerability assessment in landslide risk analysis. Erde 134:123-146

Gornitz V (1990) Vulnerability of the East Coast, USA to future sea level rise. J Coast Res 1(Special Issue No. 9):201-237

Gornitz V (1991) Global coastal hazards from future sea level rise. Palaeogeogr Palaeoclimatol Palaeoecol 89:379-398

Gornitz V (2001) Sea-level rise and coasts. In: Rosenzweig C, Solecki WD (eds) Climate change and a global city: an assessment of the metropolitan east coast region. Columbia Earth Institute, New York, pp 21-46, 210 pp

Gornitz V, Kanciruk P (1989) Assessment of global coastal hazards from sea-level rise. Coastal Zone "89. In: Proceedings of sixth symposium on coastal and ocean management, ASCE, Charleston, South Carolina, pp 1345-1359

Gornitz VM, White TW (1992) A coastal hazards database for the U.S. East Coast. Report to the US department of energy, 3913, Oak Ridge National Laboratory, TN, USA 
Guillaumont P (2008) An economic vulnerability index: its design and use for international development policy. WIDER research paper, UNUWIDER, vol November 2008/99

Harley CDG, Hughes AR, Hultgren KM, Miner BG, Sorte CJB, Thornber CS, Rodriguez LF, Tomanek L, Williams SL (2006) The impacts of climate change in coastal marine systems. Ecol Lett 9:228-241

Hatta Tatsuo (1987) Le Châtelier principle. New Palgrave Dict Econ 3:155-157

Holling CS (1973) Resilience and stability of ecological systems. Annu Rev Ecol Syst 4:1-23

Hoozemans FMJ, Stive MJF, Bijlsma L (1993) Global vulnerability assessment: vulnerability of coastal areas to sea-level rise. American Shore and Beach Preservation Association, ASCE

Hufschmidt G (2011) A comparative analysis of several vulnerability concepts. Nat Hazards. doi: 10.1007/s11069-011-9823-7 (Published online on 17th of May 2011)

Hughes P, Brundrit GB (1992) An index to assess South Africa's vulnerability to sea-level rise. South Afr Journal of Science 88:308-311

Hutchings PA, Collett LC (1977) Guidelines for the protection and management of estuaries and estuarine wetlands. Australian Marine Sciences Association, Toowong

International Institute for Applied Systems Analysis (IIASA) (2008) Economic growth in developing countries: education proves key [Online]. IIASA, Laxenburg. Available at: http://www.iiasa.ac.at/ Admin/PUB/policy-briefs/pb03-web.pdf [Accessed 15 January 2012]

IPCC (2001) Intergovernmental panel on climate change, Climate change 2001: The scientific basis. Cambridge University Press, Cambridge

IPCC (2007a) Climate change, impacts, adaptation and vulnerability. Contribution of working group II to the fourth assessment report of the intergovernmental panel on climate change. In: Parry ML, Canziani OF, Palutikof JP, van der Linden PJ, Hanson CE (eds) Intergovernmental Panel on Climate Change (IPCC). Cambridge University Press, New York

IPCC (2007b) Intergovernmental panel on climate change, AR4, fourth assessment report: Climate Change 2007

Jian J (2008) Simulated future river discharges under IPCC SRES scenarios: Yangtze, Ganges, Brahmaputra, Blue Nile and Murray-Darling Georgia Institute of Technology, Atlanta, GA; and P. Webster, Land-Atmosphere Interactions, Part VI (Joint between the 22nd conference on hydrology and the 20th conference on climate variability and change)

Kadoya M, Chikamori H, Ichioka T (1993) Some characteristics of heavy rainfalls in the Yamato river basin found by the principal component and cluster analyses, extreme hydrological events: precipitation, floods and droughts. In: Proceedings of the Yokohama symposium, July 1993. IAHS Publ. no. 213

Kawai H, Hashimoto N, Matsuura K (2008) Estimation of extreme storm surge and its duration in Japanese Bays by using stochastical typhoon model, ICCE

Kumar PKD (2006) Potential vulnerability implications of sea level rise for the coastal zones of Cochin, Southwest Coast of India. Environ Monit Assess 123:333-344

Marcoux A (2000) Population and deforestation. [Online] Sustainable development department of the food and agriculture organization of the United Nations. Available at: http://www.fao.org/sd/wpdirect/ WPan0050.htm [Accessed 15 January 2012]

McLaughlin S, Cooper JAG (2010) A multi-scale coastal vulnerability index: a tool for coastal managers? Environ Hazards J 9:1-16. Earthscan ISSN: 1878-0059

Merz B, Thieken AH, Gocht M (2007) Flood risk mapping at the local scale: concepts and challenges. In: Begum S, Stive MJF, Hall JW (eds) Flood risk management in Europe, pp 231-251

Mirza MMQ (2003) Climate change and extreme weather events: can developing countries adapt? Clim Policy 3:233-248

Nicholls RJ (2004) Coastal flooding and wetland loss in the 21st century: changes under the SRES climate and socio-economic scenarios. Global Environ Change 14:69-86

Nicholls RJ, Wong PP, Burkett VR, Codignotto JO, Hay JE, McLean RF, Ragoonaden S, Woodroffe CD (2007) Coastal systems and low-lying areas. In: Climate change 2007: impacts, adaptation and vulnerability. contribution of working group II to the fourth assessment report of the intergovernmental panel on climate change. Cambridge University Press, Cambridge

OCDE (2007) Selon l'OCDE, le changement climatique pourrait multiplier par trois la population exposée à un risque d'inondations côtières d'ici 2070, seen on www.oecd.org/env/cc on 26th November 2009

Peduzzi P, Dao H, Herold C, Rochette D, Sanahuja H (2001) Feasibility study report-on global risk and vulnerability index - trends per year (GRAVITY). United Nations Development Programme Emergency Response Division UNDP/ERD, Geneva

Pelling M (2003) The vulnerability of cities; natural disaster and social resilience. Earthscan Publications, UK

Penning-Rowsell E, Floyd P, Ramsbottom D, Surendran S (2005) Estimating injury and loss of life in floods: a deterministic framework. Natural Hazards 36(1-2):43-64 
Perry RW (2006) "What is a disaster". In: Rodrı' guez H, Quarantelli EL, Dynes RR (eds) Handbook of disaster research. Springer, New York, pp. 1-15

Pirazzoli PA, Regnauld H, Lemasson L (2004) Changes in storminess and surges in western France during the last century. Mar Geol 210:307-323

Prakasa R, Murty BS (2005) Estimation of flood vulnerability index for delta, Geoscience and remote sensing symposium, vol 5, no 25-29, pp 3611-3614

Pratt C, Kaly U, Mitchell J (2004) How to use the Environmental Vulnerability Index, UNEP/SOPAC South Pacific Applied Geo-science Commission. Technical Report 383. www.vulnerabilityindex.net/Files/ EVI\%20Manual.pdf (accessed 17 January 2012)

Pritchard DW (1967) What is an estuary: physical viewpoint. In: Lauff GH (ed) Estuaries. American Association for the Advancement of Science, Washington, DC, pp 3-5

Quarantelli EL (2005) A social science research agenda for the disasters of the 21st century: theoretical, methodological and empirical issues and their professional implementation. In: Perry RW, Quarantelli EL (eds) What is a disaster? New Answers to Old Questions. Xlibris, Philadelphia, pp 325-396

Regnauld H, Pirazzoli PA, Morvan G, Ruz M (2004) Impact of storms and evolution of the coastline in western France. Mar Geol 210:325-337

Saalmueller J (n.d.) Flood management: why it matters for development and adaptation policy. [Online] Available at: http://es.scribd.com/doc/53885460/Flood-Management-Why-It-Matters-for-Develop ment-and-Adaptation-Policy [Accessed 13 January 2012]

Scheuer S, Haase D, Meyer V (2010) Exploring multicriteria flood vulnerability by integrating economic, social and ecological dimensions of flood risk and coping capacity: from a starting point view towards an end point view of vulnerability. Nat Hazards (Published on 1st December 2010, DOI 10.1007/ s11069-010-9666-7)

Sharples C (2006) Indicative mapping of Tasmanian coastal vulnerability to climate change and sea-level rise: explanatory report (Second Edition). Department of Primary Industries and Water, Hobart, Tasmania, pp i-iv, 1-173. ISBN 0-7246-6385-1 [Revision/New Edition]

Small C, Nicholls RJ (2003) A global analysis of human settlement in coastal zones. J Coast Res 19:584-599

Smit B, Wandel J (2006) Adaptation, capacity and vulnerability. Global Environ Change 16:282-292

Smith K, Ward R (1998) Floods: physical processes and human impacts. Wiley, Chichester

Sorenson JH, Sorensen BV (2006) Community processes: warning and evacuation. In: Rodríguez H, Quarantelli EL, Dynes RR (eds) Handbook of disaster research, Springer. New York, NY, pp 183-199

Thieler ER, Hammer-Klose ES (2000) National assessment of coastal vulnerability to sea-level rise: preliminary results for the US Pacific Coast. United States Geological Survey (USGS), Woods Hole, Open File Report 00-178, $1 \mathrm{p}$

UNEP (2002) Global environment outlook 3. Earthscan, London, p 446

UNEP (2006) Raising awareness of climate change, a handbook of government focal points, Published October, 2006. As seen on: http://www.unep.org/dec/docs/UNEP_Climate_Change_Handbook.pdf on 19th of January, 2012

United Nation (UN) (2003) Guidelines on participatory planning and management for flood mitigation and preparedness, ix, 129 s.: ill., Water resources series, 0082-8130, no. 82, United Nations: New York

United Nations Population Fund (UNFPA) (2011a) Linking population, poverty and development (rapid growth in less developed regions) [Online] Available at: http://www.unfpa.org/pds/trends.htm [Accessed 13 January 2012]

United Nations Population Fund (UNFPA) (2011b) Linking population, poverty and development (Urbanization: a majority in cities) [Online] Available at: http://www.unfpa.org/pds/urbanization.htm [Accessed 13 January 2012]

van Beek E (2006) Water resources development, UNESCO-IHE, Lecture notes

Villagran de Leon JC (2006) Vulnerability - a conceptual and methodological review. UNU EHS, no 4/2006, Bonn, Germany

Walstra D-J (2009) Climate proofing coastal defence strategies. Deltares-Delft Hydraulics Delft University of Technology

Watts MJ, Bohle HG (1993) The space of vulnerability: the causal structure of hunger and famine. Progr Human Geogr 17:43-67

Webster PJ, Holland GJ, Curry JA, Chang HR (2005) Changes in tropical cyclone. Number, duration, and intensity in a warming environment. Science 309(5742):1844-1846

Willroth P, Revilla Diez J, Aruntai N (2010) Modelling the economic vulnerability of households in the Phang-Nga Province (Thailand) to natural disasters. Nat Hazards. doi:10.1007/s11069-010-9635-1 (Published online on 9th of October 2010)

Woodroffe CD (2003) Coasts: form, process and evolution. Cambridge University Press, Cambridge 
World Bank (1994) Social indicators of development. World Bank, Washington, DC

World Bank (1997) Expanding the measure of wealth indicators of environmentally sustainable development, Rio 5th edn, discussion draft. World Bank, Washington, DC

World Bank (2005) African development indicators 2005. www4.worldbank.org/afr/stats/adi2005/ adi05_booklet_rev_061505.pdf (accessed 16 November 2009)

WWF (2009) Mega-stress for mega-cities a climate vulnerability ranking of major coastal cities in Asia. WWF for a living planet report

Yusuf AA, Francisco HA (2009) Climate change vulnerability mapping for Southeast Asia, economy and environment program for Southeast Asia (EEPSEA), Singapore, www.eepsea.org

Zoleta-Nantes DB (1999) The flood landscapes of Metro Manila. Chronicle 4(1-2) 